\title{
Mobilya üretimi yapan küçük ölçekli işletmelerin iş sağlığı ve güvenliğine yönelik algı düzeylerinin incelenmesi: Bilecik ili örneği
}

\author{
Mustafa Uğuz ${ }^{1}$ (D), Eyüp Aksoy² (D), Hakan Keskin ${ }^{1 *}$ (D)
}

$\ddot{\mathbf{O} z}$

İş sağlığı ve güvenliği, kişinin en temel hakkı olan yaşam hakkının devam ettirilebilmesi bakımından bireyin çalışma ortamında bulunan riskler ile güvensiz durum ve davranışlardan korunmasına yönelik faaliyetleri kapsamaktadır. Büyük riskler barındıran mobilya imalatı sektöründe, literatüre bakıldığında iş sağlığı ve güvenliği bakımından yeterli düzeyde çalışma yapılmadığı görülmektedir. Bu çalışmada, mobilya üretiminde görev alan kişilerin çalıştıkları işyerlerinde uygulanan iş sağlığı ve güvenliği çalışmalarının ne düzeyde olduğu ve bunlara yönelik çözümlerin neler olabileceği konusu incelenmiştir. Bu kapsamda; Bilecik ilindeki mobilya üretimi yapan küçük ölçekli işyerlerinde çalışan kişilerin, maruz kaldığı iş kazaları ile bu kazalara bakış açılarının ve çalışmakta oldukları işyerlerinde iş sağlığı ve güvenliği açısından yapılan faaliyetlerin yeterlilik düzeylerinin belirlenip; bunların çözümüne yönelik önerilerin oluşturulmasının amaçlandığı bu çalışmadaki veriler, çalışanlara uygulanan anket çalışması ile elde edilmiştir. Çalışma sonucunda; iş kazalarının önlenmesi ya da azaltılması için işyerlerinde alınan önlemler ile uyarı işaret ve levhalarının çalışanları kısmen koruduğu; güvenli çalışma kılavuzu ve çalışma talimatlarının çalışanı yeterince koruyamadığı; yangın, acil durum ve ilkyardım ile ilgili alınan önlemlerin yeterli düzeyde olmadığı tespit edilmiştir.

Anahtar kelimeler: Mobilya üretimi, İş sağllğı ve güvenliği, Algı düzeyi, Bilecik ili örneği

\section{Investigation of the perception levels of occupational health and safety in small-scale enterprises making furniture production: Bilecik province sample}

\begin{abstract}
Occupational health and safety covers the activities of the individual in the working environment to protect the right of life, which is the most basic right of the person, and the activities to protect them from unsafe situations and behaviors. Considering the literature, it is sent that there is not enough work in terms of occupational health and safety. In this study, the level of occupational health and safety studies applied in the work places of people working in furniture production and what can be the solutions for the mare examined. In this context; Personnel working in small-scale establishments producing furniture in Bilecik province are determined by their occupational accidents and their occupational health and safety in terms of their occupational health and safety. The data in this study, which is intended to provide suggestions for the solution of these problems, has been obtained by a questionnaire applied to the employees. In the results of working; measures taken at work places to prevent or reduce occupational accidents and warning signs and signs partially protect employees; safe working manual and workingin structions cannot adequately protect the employee; fire, emergency and first aid measures were not sufficient.
\end{abstract}

Keywords: Furniture production, Occupational health and safety, Perception level, Bilecik province sample

Makale tarihçesi: Geliș:06.02.2019, Kabül:09.06.2019, Yayınlanma: 28.06.2019, *Sorumlu yazar: khakan@gazi.edu.tr ${ }^{1}$ Gazi Üniversitesi, Teknoloji Fakültesi, Ağaçişleri Endüstri Mühendisliği Bölümü, 06500 Teknikokullar - Ankara /Türkiye ${ }^{2}$ Afyon Kocatepe Üniversitesi, Afyon Meslek Yüksekokulu,İc Mekan Tasarımı Programı - Afyonkarahisar / Türkiye Atıf: Uguz, M., Aksoy, E., Keskin, H., (2019), Mobilya üretimi yapan küçük ölçekli işletmelerin iş sağlığı ve güvenliğine yönelik algı düzeylerinin incelenmesi: Bilecik ili örneği, Mobilya ve Ahşap Malzeme Araştırmaları Dergisi, 2(1), 30-45 


\section{Giriş}

İş Sağlığı ve Güvenliği (İSG) ile ilgili çalışmaların hedefi öncelikli olarak, iş kazalarının önlenmesi şeklinde algılanmaktadır. Türkiye'de İSG mevzuatının uygulanması, 2014 yılına kadar 50 ve daha fazla çalışanı olan işyerlerini kapsamakla sınırlı kaldığından; küçük ve orta ölçekli üretim yapan birçok işyerinde, çalışanların yaptıkları işten ve iş ortamından kaynaklı sağlık ve güvenlik tehlikelerinden korunabilmeleri işyeri sahibinin inisiyatifine bırakılmıştır. İş kazalarının, işyeri büyüklüklerine göre dağılımı incelendiğinde;çoğunluğun küçük işyerlerinde olduğu gerçeği görülmektedir. İş güvenliğinin sağlanmasında ileri teknoloji kullanılması, otomasyona geçilmesi, makinelerin standartlara uygun olması,makine koruyucularının takılı olması ve yapılan işe uygun kişisel koruyucuların kullanılması gerekmektedir.

Mobilya imalatı sektörü, 26.12.2012 tarih ve 28509 sayılı Resmi Gazetede yayımlanan İş Sağlığı ve Güvenliğine İlişkin İşyeri Tehlike Sınıfları Tebliğine göre "tehlikeli" sınıftaki işyerleri arasında yer almaktadır (ÇSGB, 2012).

Arseven (2004), sanayileşmedeki hızlı gelişme ve işyerlerinde yeterli önlemlerin alınmamasıyla artan iş kazaları ve meslek hastalıkları, iş sağlığı ve güvenliğine verilen önemin arttığını vurgulamaktadır. Ford ve ark. (2011), çalışan güvenliğinin, organizasyonun yapısından bağımsız olarak, diğer mesleklere göre, daha büyük tehdit altında olabileceğini; geçmişte mesleksel yaralanma riskinin çalışanın tutum ve alışkanlıkları temelinde değerlendirildiğini, mevcut çalışmaların ise kişinin meslek özelliklerinden bağımsız olarak ölçülen mesleksel tehlikelerle ilgili olduğunu ifade etmekte; çalışanın mesleksel rolünün, beklenileni yapması ve yaptığı işin doğasında bulunan tehlikeler ölçüsünde genişletilebileceğini vurgulamaktadırlar. Şimşek (2012), işle ilgili hastalıkları; işyerinde var olan birçok nedensel faktör ve başka risk faktörlerinin birlikte rol oynadığı, kompleks hastalıklar olarak tanımlamakta ve hastalık etkeninin işyerinde olmasının zorunlu olmadığını belirtmektedir. Ayrıca, yapılan işin hastalığa neden olduğunu, ağırlaştırdığını, hızlandırdığını ya da alevlendirdiğini belirtmekte ve böylece çalışanın çalışma kapasitesinin azalabileceğini öne sürmektedir. Aynı olguda aynı sonuçlar çıkmasının farklı nedenlere bağlı olabileceğini, işle ilgili hastalıkların meslek hastalıklarına göre daha sık ve çalışanlar kadar toplumun genelinde de görülebileceğini de belirtmektedir. Kalkan (2013), günümüzün iş dünyasında önemli bir rol oynayan İSG konusunu irdelemiş olup; geçmişten günümüze yapılan çalışmaları, bu alanda kilit basamak olan risk değerlendirme tekniklerini ve genel hali ile uygulama şekillerini anlatmış, sektör alanına göre çok çeşitli tehlikeli çalışmaları ihtiva eden bir mobilya üretim işletmesinin döşeme bölümünde bu tekniklerin uygulamasını yapmıştır. Turan (2013), ahşap malzemeden mobilya üretimi yapan örnek bir tesiste iş faktörlerinden kaynaklanan çevresel etkilerin, çalışan sağlığı üzerinde oluşturacağı etkileri tanımlamayı amaçladığı çalışmasında; mobilya üretiminin temel üretim süreçlerinde, çalışanın karşılaştığ sağlık tehditlerini incelemiş, çalışan sağlığına etki eden faktörlere ait iç ortam ölçümü sonuçlarından ve kişisel maruziyet değerlerinden yararlanarak, çalışanın hangi yolla sağlık zararına uğrayabileceğini tespit etmiştir. Ayrıca çalışanların, çalışma ortamındaki etkiler ile birlikte dış ortam kalitesinden de zarar görebilecekleri gerçeğinden yola çıkarak söz konusu işletmenin atık su karakterizasyonu, baca gazı ve toz emisyonu ile katı atık türü ve miktarının da, çevre ve insan sağlığı üzerinde oluşturabileceği etkileri tespit etmiştir. Gedik ve İlhan (2014), Sakarya ilinde faaliyette bulunan mobilya işletmelerinde çalışanların,iş ortamlarında yaşadıkları olumsuzlukları ve bu olumsuzluklardan kaynaklanan iş kazası ve meslek hastalığına maruz kalma durumlarını analiz ettiği çalışmalarında; 2011 yılı Haziran ayında, 24 farklı işletmedeki 227 çalışana anket uygulamıştır. Çalışma sonucunda; Sakarya ilinde, 
Türkiye ortalamasından daha yüksek oranda iş kazası ve meslek hastalığı meydana geldiğini belirlemişlerdir. Bunun sebebinin, gürültü, ortam sıcaklığı, solunumla alınan gaz ve tozlar, eskimiş ya da bakımı yapılmamış el aletleri, kullanılan el aletlerinin/makinelerin bakımlarının düzenli yapılmaması, düzensiz ve dağınık çalışma ortamı ve yetersiz uyarı levhalarından kaynaklandığını tespit etmişlerdir.

Birtekin (2015), Hatay ve Gaziantep illerinde ahşap işleri ve mobilya üretimi yapılan işletmelerde, iş sağlığı ve güvenliği tedbirlerinin bilinebilirliğgini araştırdığı çalışma sonucunda; çalışanların \%27'sinin kazaya maruz kaldığını, \%10'unun Çalışma ve Sosyal Güvenlik Bakanlığının iş sağlığı ve güvenliği tedbirleri ile uyulması gereken kurallar ile ilgili hiç bilgisi olmadığını, \%62'sinin ise kısmen bilgisi olduğunu tespit etmiş; iş kazalarının genelde iş yerlerindeki elverișsiz ortam koşullarından, yerleşim planı hatalarından ve insan faktörüne ait yetersizliklerden, eğitim ve denetim eksikliğinden ya da bütün bu faktörlerin etkileşiminden ortaya çıktığını belirlemiştir. Yine bu faktörlerin yanında, iş ortamında bulunan stresleri de dikkate almanın, neden sonuç ilişkileri açısından önemli olduğunu vurgulamıştır. Uygun (2015), mobilya sektörünü iş sağlığı ve güvenliği açısından incelediği çalışmasında; biri yerel pazarda, diğeri uluslararası pazarlarda faaliyet gösteren iki mobilya işletmesinin, iş sağlığ ve güvenliği kanununun yürürlüğe girmesini takiben karşılaştıkları iş kazaları açısından incelemiş ve iki işletme arasında karşılaştırma yapmıştır. Yılmaz (2015), çalışmasında, Ankara ilinde faaliyet gösteren 9 mobilya firmasında çalışan 112 kişiyle anket çalışması gerçekleştirmiştir. Bunun yanında, Fine-Kinney Risk Değerlendirme Yöntemini kullanarak yaptığı analizlerle, mobilya imalatı yapan işletmelerdeki iş güvenliği tedbirlerine yönelik durum tespiti yapmıştır. Yapılan çalışmalar sonucunda elde ettiği verileri dikkate alarak değerlendirmeler yapmış ve öneriler sunmuştur. Koç (2016), çalışmasında, öncelikle işle ilgili kas iskelet sistemi rahatsızlıklarını çok yönlü olarak ele almış, literatürde yer alan ergonomik risk değerlendirme metotlarına yer vermiş ve mobilya imalatındaki işe bağlı kas iskelet sistemi sorunlarına değinmiştir. Son olarak, tehlikeli sınıfta yer alan bir mobilya fabrikasında bunların uygulamasını gerçekleştirmiştir. Ulay ve Engür (2016), İSG uygulamalarının yıllık maliyetinin ortaya konulması, mobilya sektöründeki olumlu uygulama örneklerinin yaygınlaştırılması ve bilgi eksikliklerinin acil olarak giderilmesini amaçladığı çalışmalarında; masif mobilya üreten örnek bir işletmede kişisel koruyucu donanımları satın alma, güvenliğe yönelik bakım ve yasal iş güvenliği eğitimlerinin yıllık maliyetlerini belirlemiştir. Şen ve Çınar (2017), mobilya yaşam döngüsü kapsamında, sektörde uygulanan iş güvenliği uygulamalarını, iş sağlığı ve güvenliği sorunlarını; çalışma alışkanlıklarını, iş kazalarını, meslek hastalıklarını ve ortak yönlerini incelemiş, bu konular ile ilgili çözümlerin getirilmesini amaçlamışlardır. Bu doğrultuda; mikro, küçük, orta ve büyük ölçekli mobilya işletmelerine yönelik çalışanlar ve yöneticiler için iki farklı anket uygulamışlardır. Çalışma sonuçlarına göre; iş kazalarının azalması ve meslek hastalıklarının önlenmesi adına alınan tedbirler ve eğitimler için işletmelerin büyümesi gerektiğini, iş sağlı̆̆ı ve güvenliği için mikro ve küçük işletmelerin birleşerek; büyümelerinin devlet tarafından desteklenmesi gerektiğini vurgulamışlardır. Zor ve ark. (2017), Zonguldak ilinde faaliyette bulunan mobilya işletmelerinde çalışanların, çalışma ortamlarında yaşadıkları olumsuzluklar ve bu olumsuzluklardan kaynaklanan iş kazası ve meslek hastalığına maruz kalma durumlarını analiz etmiştir. Çalışma sonucuna göre, çalışanların; vücudun zorlanmasından ileri gelen incinmeler, kesici-batıcı alet kullanımından ve çalışma ortamındaki gürültüden en çok etkilendiklerini tespit etmiştir. İşletmelerde, iş güvenliği ve meslek hastalıklarına bağlı olarak ortaya çıkabilecek kaza ve kayıpların en aza indirilmesinde iş sağlı̆̆ ve güvenliğine yönelik sistemlerin geliştirilmesi, bunun yanında iş sağlığ 1 ve güvenliğine yönelik risk analizlerinin başarılı bir biçimde gerçekleştirilmesinin oldukça önemli olduğunu belitmişlerdir. 
$\mathrm{Bu}$ çalışmada, Bilecik ilindeki mobilya üretimi sektöründe çalışan kişilerin, görev yapmakta oldukları işyerlerinde uygulanan iş sağlığı ve güvenliği çalışmalarının düzeyinin ve bu konudaki sorunların belirlenerek; bunlara yönelik çözüm önerilerinin sunulması amaçlanmıştır.

\section{Materyal ve Metot}

Bilecik ili mobilya endüstrisinde değişik kademelerde çalışan,tamamen tesadüfî yöntemle seçilen toplam 50 çalışana anket uygulanmıştır. Anket sonuçları, SPSS 15.0 istatistik paket programı ile analiz edilmiştir. Sözkonusu ankette, katılımcıların;

- Demografik özellikleri,

- İş kazası geçirme durumları ve sonuçları,

- İş kazası ve meslek hastalıklarını meydana getiren fiziksel tehlikeler,

- İş kazasını meydana getirebilecek çalışma şartları,

- İş kazası ile ilgili çalışma alanında meydana gelen tehlikeler,

- Çalışma ortamlarında iş kazalarına neden olabilecek olumsuzluklar irdelenerek çalışanların bilinç düzeyleri ele alınmıştır.

Demografik özellikler haricindeki soruların tümü beşli likert tipi ölçek kullanılarak uygulanmış olup 1: Hiç katılmıyorum, 2: Katılmıyorum, 3: Kısmen katılıyorum, 4: Katılıyorum, 5: Tamamen katılıyorum şeklinde ifade edilmektedir. Bu ölçeğin güvenilirliği Cronbachalpha $(\alpha)$ katsayısı ile ölçülmüştür.

\section{Bulgular ve Tartışma}

Çalışmaya konu olan işyerleri ile bu iş yerlerinde çalışan kişilerin yaşlarına göre dağılımı Çizelge 1'de verilmiştir.

Çizelge 1.Çalışmaya konu olan işyerleri ile bu iş yerlerinde çalışanların yaşlarına göre dağılımı

\begin{tabular}{|c|c|c|c|c|c|c|c|}
\hline \multirow{2}{*}{\multicolumn{2}{|c|}{ İşyeri Adı }} & \multicolumn{5}{|c|}{ Yaş Aralığı } & \multirow{2}{*}{$\begin{array}{l}\text { İsyerlerine Göre Toplam } \\
\text { Çalşan Saylart }\end{array}$} \\
\hline & & $25-40$ & \multirow{2}{*}{\begin{tabular}{|l|}
40 ve üzeri \\
2 \\
\end{tabular}} & \multirow{2}{*}{$\begin{array}{l}\mathbf{1 8 - 2 5} \\
1\end{array}$} & \multirow{2}{*}{\begin{tabular}{|l|}
$\mathbf{1 5 - 1 8}$ \\
1
\end{tabular}} & \multirow{2}{*}{$\begin{array}{l}14-15 \\
0\end{array}$} & \\
\hline 2M $\quad$ Yapı & Çalışan Sayısı & 4 & & & & & 8 \\
\hline Dekorasyon & Oranı (\%) & 50.00 & 25.00 & 12.50 & 12.50 & 0.00 & 100.00 \\
\hline \multirow{2}{*}{$\begin{array}{l}\text { Demob } \\
\text { Dekorasyon }\end{array}$} & Çalışan Sayısı & 4 & 2 & 1 & 0 & 0 & 7 \\
\hline & Oranı (\%) & 57.14 & 28.57 & 14.29 & 0.00 & 0.00 & 100.00 \\
\hline \multirow{2}{*}{ Lila Dekor } & Çalışan Sayısı & 3 & 2 & 1 & 0 & 0 & 6 \\
\hline & Oranı (\%) & 50.00 & 33.33 & 16.67 & 0.00 & 0.00 & 100.00 \\
\hline \multirow{2}{*}{$\begin{array}{l}\text { Simetri } \\
\text { Mobilya }\end{array}$} & Çalıșan Sayısı & 4 & 1 & 1 & 0 & 0 & 6 \\
\hline & Oranı (\%) & 66.67 & 16.67 & 16.67 & 0.00 & 0.00 & 100.00 \\
\hline \multirow{2}{*}{$\begin{array}{l}\text { Ege } \\
\text { Mobilya }\end{array}$} & Çalışan Sayısı & 3 & 1 & 1 & 1 & 0 & 6 \\
\hline & Oranı (\%) & 50.00 & 16.67 & 16.67 & 16.67 & 0.00 & 100.00 \\
\hline \multirow{2}{*}{$\begin{array}{l}\text { Köksal } \\
\text { Mobilya }\end{array}$} & Çalışan Sayısı & 4 & 0 & 0 & 0 & 0 & 4 \\
\hline & Oranı (\%) & 100.00 & 0.00 & 0.00 & 0.00 & 0.00 & 100.00 \\
\hline \multirow{2}{*}{$\begin{array}{l}\text { Filiz } \\
\text { Mobilya }\end{array}$} & Çalıșan Sayısı & 2 & 1 & 0 & 0 & 0 & 3 \\
\hline & Oranı (\%) & 66.67 & 33.33 & 0.00 & 0.00 & 0.00 & 100.00 \\
\hline \multirow{2}{*}{$\begin{array}{l}\text { Era } \\
\text { Mobilya }\end{array}$} & Çalışan Sayısı & 2 & 1 & 0 & 0 & 0 & 3 \\
\hline & Oranı (\%) & 66.67 & 33.33 & 0.00 & 0.00 & 0.00 & 100.00 \\
\hline \multirow{2}{*}{$\begin{array}{l}\text { Re-Ha } \\
\text { Mobilya }\end{array}$} & Çalışan Sayısı & 3 & 0 & 0 & 0 & 0 & 3 \\
\hline & Oranı (\%) & 100.00 & 0.00 & 0.00 & 0.00 & 0.00 & 100.00 \\
\hline \multirow{2}{*}{$\begin{array}{l}\text { Vira-Door } \\
\text { Mobilya }\end{array}$} & Çalışan Sayısı & 3 & 0 & 0 & 0 & 0 & 3 \\
\hline & Oranı (\%) & 100.00 & 0.00 & 0.00 & 0.00 & 0.00 & 100.00 \\
\hline \multirow{2}{*}{$\begin{array}{l}\text { İmparator } \\
\text { Mobilya }\end{array}$} & Çalışan Sayısı & 0 & 1 & 0 & 0 & 0 & 1 \\
\hline & Oranı (\%) & 0.00 & 100.00 & 0.00 & 0.00 & 0.00 & 100.00 \\
\hline \multirow{2}{*}{ 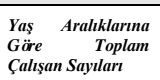 } & Çalışan Sayısı & 32 & 11 & 5 & 2 & 0 & 50 \\
\hline & Oranı (\%) & 64.00 & 22.00 & 10.00 & 4.00 & 0.00 & 100.00 \\
\hline
\end{tabular}


Çizelge 1'e göre, araştırmaya katılan 11 firmadaki toplam 50 çalışandan, yaşları bakımından en yüksek 25-40 yaş grubu ile 2M Yapı Dekorasyon, Demob Dekorasyon, Simetri Mobilya, Köksal Mobilya firmalarında olduğu belirlenmiştir. En düşük ise; 14-15 yaş grubunda olduğu ve bu yaş aralığında hiçbir çalışan olmadığı belirlenmiştir.

Çalışmaya konu olan işyerleri ile bu iş yerlerinde çalışan kişilerin medeni durumlarına göre dağılımı Çizelge 2'de verilmiştir. Çizelge 2'ye göre, çalışanların medeni durumları bakımından en yüksek 25-40 yaş grubunda ve evli olduğu belirlenmiştir.

Çizelge 2. Çalışmaya konu olan işyerleri ile bu iş yerlerinde çalışan kişilerin medeni durumlarına göre dağılımı

\begin{tabular}{|c|c|c|c|c|c|c|c|}
\hline \multirow{2}{*}{\multicolumn{2}{|c|}{ Medeni Durumu }} & \multicolumn{5}{|c|}{ Yaş Aralığı } & \multirow{3}{*}{$\begin{array}{l}\begin{array}{l}\text { Medeni Durumlarina Göre } \\
\text { Toplam Calıșan Sayları }\end{array} \\
35\end{array}$} \\
\hline & & \multirow{2}{*}{$\begin{array}{l}25-40 \\
25\end{array}$} & \multirow{2}{*}{$\begin{array}{l}\mathbf{4 0} \text { ve üzeri } \\
10\end{array}$} & \multirow{2}{*}{$\begin{array}{l}18-25 \\
0\end{array}$} & \multirow{2}{*}{\begin{tabular}{|l|}
$15-18$ \\
0
\end{tabular}} & \multirow{2}{*}{\begin{tabular}{|l}
$14-15$ \\
0
\end{tabular}} & \\
\hline & Çalışan Sayısı & & & & & & \\
\hline EVII & Oranı (\%) & 71.43 & 28.57 & 0.00 & 0.00 & 0.00 & 100.00 \\
\hline \multirow{2}{*}{ Bekar } & Çalışan Sayısı & 7 & 1 & 5 & 2 & 0 & 15 \\
\hline & Oranı (\%) & 46.67 & 6.67 & 33.33 & 13.33 & 0.00 & 100.00 \\
\hline \multirow{2}{*}{$\begin{array}{l}\text { Yas Aralkiarma } \\
\text { Göre Toplam } \\
\text { Callsan Saylariar }\end{array}$} & Çalışan Sayısı & 32 & 11 & 5 & 2 & 0 & 50 \\
\hline & Oranı (\%) & 64.00 & 22.00 & 10.00 & 4.00 & 0.00 & 100.00 \\
\hline
\end{tabular}

Çalışmaya konu olan işyerleri ile bu iş yerlerinde çalışan kişilerin kalıcı sağlık durumlarına göre dağılım Çizelgesi 3'de verilmiştir.Çizelge 3'e göre, çalışanların, kalıcı sağlık sorunu bakımından en yüksek 25-40 yaş grubunda olduğu belirlenmiştir.

Çizelge 3. Çalışmaya konu olan işyerleri ile bu iş yerlerinde çalışan kişilerin kalıcı sağlık durumlarına göre dağılımı

\begin{tabular}{|c|c|c|c|c|c|c|c|}
\hline \multirow{2}{*}{\multicolumn{2}{|c|}{$\begin{array}{l}\text { Kalıcı Sağlık Sorunu } \\
\text { Var mı? }\end{array}$}} & \multicolumn{5}{|c|}{ Yaş Aralığı } & \multirow{2}{*}{$\begin{array}{l}\text { Kalıct Sağllk Sorunu } \\
\text { Durumlarına Gör } \\
\text { Toplam Çalışan Sayılart }\end{array}$} \\
\hline & & $25-40$ & 40 ve üzeri & $18-25$ & $15-18$ & 14-15 & \\
\hline \multirow{2}{*}{ Hayır } & $\begin{array}{l}\text { Çalışan } \\
\text { Sayısı }\end{array}$ & 32 & 11 & 5 & 2 & 0 & 50 \\
\hline & $\begin{array}{l}\text { Oranı } \\
(\%)\end{array}$ & 64.00 & 22.00 & 10.00 & 4.00 & 0.00 & 100.00 \\
\hline \multirow{2}{*}{ Evet } & $\begin{array}{l}\text { Çalışan } \\
\text { Sayısı }\end{array}$ & 0 & 0 & 0 & 0 & 0 & 0 \\
\hline & $\begin{array}{l}\text { Oranı } \\
(\%)\end{array}$ & 0.00 & 0.00 & 0.00 & 0.00 & 0.00 & 0.00 \\
\hline \multirow{2}{*}{$\begin{array}{l}\text { Yaş } \\
\text { Aralıklarına } \\
\text { Göre Toplam } \\
\text { Çalışan Sayıları }\end{array}$} & $\begin{array}{l}\text { Çalışan } \\
\text { Sayıst }\end{array}$ & 32 & 11 & 5 & 2 & 0 & 50 \\
\hline & $\begin{array}{l}\text { Orant } \\
(\%)\end{array}$ & 64.00 & 22.00 & 10.00 & 4.00 & 0.00 & 100.00 \\
\hline
\end{tabular}

Çalışmaya konu olan işyerleri ile bu iş yerlerinde çalışan kişilerin bedensel engel durumlarına göre dağılım Çizelgesi 4'te verilmiştir. Buna göre, çalışanların, bedensel engel durumu bakımından en yüksek 25-40 yaş grubunda olduğu belirlenmiştir. 
Çizelge 4. Çalışmaya konu olan işyerleri ile bu iş yerlerinde çalışan kişilerin bedensel engel durumlarına göre dağılımı

\begin{tabular}{|c|c|c|c|c|c|c|c|}
\hline \multirow{2}{*}{\multicolumn{2}{|c|}{ Bedensel Engel Durumu Var mı? }} & \multicolumn{5}{|c|}{ Yaş Aralığg } & \multirow{3}{*}{$\begin{array}{lr}\begin{array}{l}\text { Bedensel } \\
\text { Durumlartna } \\
\text { Toplam } \\
\text { Sayları }\end{array} & \begin{array}{r}\text { Engel } \\
\text { Göre } \\
\text { Çalş̧an }\end{array} \\
50 & \end{array}$} \\
\hline & & \multirow{2}{*}{$\begin{array}{l}25-40 \\
32\end{array}$} & \multirow{2}{*}{$\begin{array}{l}\mathbf{4 0} \text { ve üzeri } \\
11\end{array}$} & \multirow{2}{*}{$\begin{array}{l}18-25 \\
5\end{array}$} & \multirow{2}{*}{$\begin{array}{l}15-18 \\
2\end{array}$} & \multirow{2}{*}{$\begin{array}{l}14-15 \\
0\end{array}$} & \\
\hline & Çalışan Sayısı & & & & & & \\
\hline Пауі & Oranı (\%) & 64.00 & 22.00 & 10.00 & 4.00 & 0.00 & 100.00 \\
\hline \multirow{2}{*}{ Evet } & Çalışan Sayısı & 0 & 0 & 0 & 0 & 0 & 0 \\
\hline & Oranı (\%) & 0.00 & 0.00 & 0.00 & 0.00 & 0.00 & 0.00 \\
\hline \multirow{2}{*}{$\begin{array}{l}\text { Yaş Aralıklarına Göre Toplam } \\
\text { Çalışan Sayıları }\end{array}$} & Çalışan Sayısı & 32 & 11 & 5 & 2 & 0 & 50 \\
\hline & Oranı (\%) & 64.00 & 22.00 & 10.00 & 4.00 & 0.00 & 100.00 \\
\hline
\end{tabular}

Çalışmaya konu olan işyerleri ile bu iş yerlerinde çalışan kişilerin sigara kullanım durumlarına göre dağılım Çizelgesi 5'de verilmiştir. Buna göre, sigara kullanan çalışanların, yaş aralığı bakımından en yüksek 25-40 yaş grubunda yoğunlaştığı belirlenmiştir.

Çizelge 5. Çalışmaya konu olan işyerleri ile bu iş yerlerinde çalışan kişilerin sigara kullanım durumlarına göre dağılımı

\begin{tabular}{|c|c|c|c|c|c|c|c|}
\hline \multirow{2}{*}{\multicolumn{2}{|c|}{ Sigara Kullanıyor mu? }} & \multicolumn{5}{|c|}{ Yaş Aralığı } & \multirow{2}{*}{$\begin{array}{lr}\text { Sigara } & \text { Kullanım } \\
\text { Durumlarina } & \text { Göre } \\
\text { Toplam Çalş̧an Saylart }\end{array}$} \\
\hline & & \multirow{2}{*}{$\begin{array}{l}25-40 \\
24 \\
\end{array}$} & \multirow{2}{*}{\begin{tabular}{|l|}
40 ve üzeri \\
10 \\
\end{tabular}} & \multirow{2}{*}{$\begin{array}{l}18-25 \\
3\end{array}$} & \multirow{2}{*}{$\begin{array}{l}15-18 \\
0 \\
\end{array}$} & \multirow{2}{*}{$\frac{14-15}{0}$} & \\
\hline 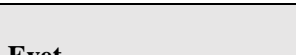 & Çalışan Sayısı & & & & & & 37 \\
\hline Cret & Oranı (\%) & 64.86 & 27.03 & 8.11 & 0.00 & 0.00 & 100.00 \\
\hline \multirow{2}{*}{ Hayır } & Çalışan Sayısı & 8 & 1 & 2 & 2 & 0 & 13 \\
\hline & Oranı (\%) & 61.53 & 7.69 & 15.38 & 15.38 & 0.00 & 100.00 \\
\hline \multirow{2}{*}{$\begin{array}{l}\text { Yaş Aralkklarına Göre } \\
\text { Toplam Çalş̧an Sayyları }\end{array}$} & Çalışan Sayısı & 32 & 11 & 5 & 2 & 0 & 50 \\
\hline & Oranı (\%) & 64.00 & 22.00 & 10.00 & 4.00 & 0.00 & 100.00 \\
\hline
\end{tabular}

Çalışmaya konu olan işyerleri ile bu iş yerlerinde çalışan kişilerin sigara kullanım adetlerine göre dağılım Çizelgesi 6'da verilmiştir. Buna göre, çalışanların, yaş aralığı bakımından en yüksek sigara kullanım sayısının 25-40 yaş grubunda yoğunlaştığ belirlenmiştir.

Çizelge 6. Çalışmaya konu olan işyerleri ile bu iş yerlerinde çalışan kişilerin sigara kullanım sayılarına göre dağılımı

\begin{tabular}{|c|c|c|c|c|c|c|c|}
\hline \multirow{2}{*}{\multicolumn{2}{|c|}{ Sigara Kullanım Sayısı }} & \multicolumn{5}{|c|}{ Yaş Aralığı } & \multirow{2}{*}{\begin{tabular}{|lc}
$\begin{array}{l}\text { Sigara } \\
\text { Göre }\end{array}$ \\
Sayllantart
\end{tabular}} \\
\hline & & \multirow{2}{*}{\begin{tabular}{|c|}
$25-40$ \\
12 \\
\end{tabular}} & \multirow{2}{*}{$\frac{40 \text { ve üzeri }}{3}$} & \multirow{2}{*}{\begin{tabular}{|c|}
$18-25$ \\
0
\end{tabular}} & \multirow{2}{*}{$\begin{array}{c}\mathbf{1 5 - 1 8} \\
0\end{array}$} & \multirow{2}{*}{\begin{tabular}{|c|}
$\mathbf{1 4 - 1 5}$ \\
0
\end{tabular}} & \\
\hline $15-20$ & Çalışan Sayısı & & & & & & 15 \\
\hline $15-20$ & Oranı (\%) & 80.00 & 20.00 & 0.00 & 0.00 & 0.00 & 100.00 \\
\hline \multirow{2}{*}{$0-5$} & Çalışan Sayısı & 9 & 1 & 2 & 2 & 0 & 14 \\
\hline & Oranı (\%) & 64.29 & 7.14 & 14.29 & 14.29 & 0.00 & 100.00 \\
\hline \multirow{2}{*}{20 ve üzeri } & Çalışan Sayısı & 6 & 5 & 0 & 0 & 0 & 11 \\
\hline & Oranı (\%) & 54.55 & 45.45 & 0.00 & 0.00 & 0.00 & 100.00 \\
\hline \multirow{2}{*}{$10-15$} & Çalışan Sayısı & 3 & 1 & 1 & 0 & 0 & 5 \\
\hline & Oranı (\%) & 60.00 & 20.00 & 20.00 & 0.00 & 0.00 & 100.00 \\
\hline \multirow{2}{*}{$5-10$} & Çalışan Sayısı & 2 & 1 & 2 & 0 & 0 & 5 \\
\hline & Oranı (\%) & 40.00 & 20.00 & 40.00 & 0.00 & 0.00 & 100.00 \\
\hline \multirow{2}{*}{$\begin{array}{lr}\text { Yas } & \text { Aralklarna } \\
\text { Göre } & \text { Toplam } \\
\text { Çalşan Sayları }\end{array}$} & Çalışan Saytst & 32 & 11 & 5 & 2 & 0 & 50 \\
\hline & Oranı (\%) & 64.00 & 22.00 & 10.00 & 4.00 & 0.00 & 100.00 \\
\hline
\end{tabular}


Çalışmaya konu olan işyerleri ile bu iş yerlerinde çalışan kişilerin uzmanlık alanlarına göre dağılım Çizelgesi 7'de verilmiştir. Buna göre, çalışanların yaş aralığı bakımından uzmanlaştığı alanlar incelendiğinde, en çok 25-40 yaş aralığındaki çalışanların olduğu ve bunların birleştirme işlemlerinde çalıştığı görülmüştür.

Çizelge 7. Çalışmaya konu olan işyerleri ile bu iş yerlerinde çalışan kişilerin uzmanlık alanlarına göre dağılımı

\begin{tabular}{|c|c|c|c|c|c|c|c|}
\hline \multirow{2}{*}{\multicolumn{2}{|c|}{ Uzmanlık Alanı }} & \multicolumn{5}{|c|}{ Yaş Aralığı } & \multirow{3}{*}{$\begin{array}{l}\begin{array}{l}\text { Uzmanllk Alanlarna } \\
\text { Toplam Çalsan Saylari }\end{array} \\
11\end{array}$} \\
\hline & & \multirow{2}{*}{\begin{tabular}{|l|}
$25-40$ \\
9
\end{tabular}} & \multirow{2}{*}{\begin{tabular}{|l|}
40 ve üzeri \\
1
\end{tabular}} & \multirow{2}{*}{\begin{tabular}{|l|}
$\mathbf{1 8 - 2 5}$ \\
1
\end{tabular}} & \multirow{2}{*}{\begin{tabular}{|l|}
$\mathbf{1 5 - 1 8}$ \\
0
\end{tabular}} & \multirow{2}{*}{\begin{tabular}{|l|}
$\mathbf{1 4 - 1 5}$ \\
0 \\
\end{tabular}} & \\
\hline Birlostirme & Çalışan Sayısı & & & & & & \\
\hline Borleşurme & Oranı (\%) & 82.00 & 9.00 & 9.00 & 0.00 & 0.00 & 100.00 \\
\hline \multirow{2}{*}{ Kaba Kesim } & Çalışan Sayısı & 8 & 2 & 0 & 0 & 0 & 10 \\
\hline & Oranı (\%) & 80.00 & 20.00 & 0.00 & 0.00 & 0.00 & 100.00 \\
\hline \multirow{2}{*}{ Teslimat ve Montaj } & Çalışan Sayısı & 4 & 6 & 0 & 0 & 0 & 10 \\
\hline & Oranı (\%) & 40.00 & 60.00 & 0.00 & 0.00 & 0.00 & 100.00 \\
\hline \multirow{2}{*}{ Diğer } & Çalışan Sayısı & 5 & 1 & 3 & 1 & 0 & 10 \\
\hline & \begin{tabular}{|l|} 
Oranı (\%) \\
\end{tabular} & 50.00 & 10.00 & 30.00 & 10.00 & 0.00 & 100.00 \\
\hline \multirow{2}{*}{ İnce Kesim } & Çalışan Sayısı & 3 & 1 & \begin{tabular}{|l|}
0 \\
\end{tabular} & 0 & 0 & 4 \\
\hline & Oranı (\%) & 75.00 & 25.00 & 0.00 & 0.00 & 0.00 & 100.00 \\
\hline \multirow{2}{*}{ Kenar ve Yüz Kaplama } & Çalışan Sayısı & 2 & 0 & 0 & 1 & 0 & 3 \\
\hline & \begin{tabular}{|l|} 
Oranı (\%) \\
\end{tabular} & \begin{tabular}{|l|}
66.70 \\
\end{tabular} & 0.00 & 0.00 & 33.30 & 0.00 & 100.00 \\
\hline \multirow{2}{*}{ Üstyüzey } & Çalışan Sayısı & 1 & 0 & 0 & 0 & 0 & 1 \\
\hline & \begin{tabular}{|l|} 
Oranı (\%) \\
\end{tabular} & 100.00 & 0.00 & 0.00 & 0.00 & 0.00 & 1.00 \\
\hline \multirow{2}{*}{ Ambalaj ve Sevkiyat } & Çalışan Sayısı & \begin{tabular}{|l|}
0 \\
\end{tabular} & 0 & \begin{tabular}{|l|}
1 \\
\end{tabular} & 0 & 0 & 1 \\
\hline & Oranı (\%) & 0.00 & 0.00 & 100.00 & 0.00 & 0.00 & 100.00 \\
\hline \multirow{2}{*}{ Şekillendirme } & Çalışan Sayısı & 0 & 0 & 0 & 0 & 0 & 0 \\
\hline & \begin{tabular}{|l|} 
Oranı (\%) \\
\end{tabular} & 0.00 & 0.00 & 0.00 & 0.00 & 0.00 & 0.00 \\
\hline \multirow{2}{*}{$\begin{array}{l}\text { Yaş Araltklarna Göre Toplam } \\
\text { Calişan Saylart }\end{array}$} & Çalışan Sayısı & 32 & 11 & 5 & 2 & 0 & 50 \\
\hline & Orant (\%) & 64.00 & 22.00 & 10.00 & 4.00 & 0.00 & 100.00 \\
\hline
\end{tabular}

Çalışmaya konu olan işyerleri ile bu iş yerlerinde çalışan kişilerin mesleki tecrübe sürelerine göre dağılım Çizelgesi 8 'de verilmiştir. Buna göre, çalışanların yaş aralığ1 bakımından mesleki tecrübeleri incelendiğinde en çok 25-40 yaş aralığı ile 5-10 yıl tecrübeli olduğu gözlemlenmiştir.

Çizelge 8. Çalışmaya konu olan işyerleri ile bu iş yerlerinde çalışan kişilerin mesleki tecrübe sürelerine göre dağglımı

\begin{tabular}{|c|c|c|c|c|c|c|c|}
\hline \multirow{2}{*}{\multicolumn{2}{|c|}{ Mesleki Tecrübe (Yıl) }} & \multicolumn{5}{|c|}{ Yaş Aralığı } & \multirow{2}{*}{ 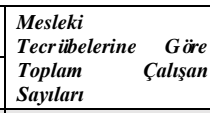 } \\
\hline & & \multirow{2}{*}{\begin{tabular}{|l|}
$25-40$ \\
15
\end{tabular}} & \multirow{2}{*}{$\begin{array}{l}40 \text { ve üzeri } \\
3\end{array}$} & \multirow{2}{*}{$\frac{\mathbf{1 8 - 2 5}}{0}$} & \multirow{2}{*}{$\frac{\mathbf{1 5 - 1 8}}{0}$} & \multirow{2}{*}{$\frac{\mathbf{1 4 - 1 5}}{0}$} & \\
\hline & Çalışan & & & & & & 18 \\
\hline 5-10 & $\begin{array}{l}\text { Oranc } \\
\text { Oran } \\
\end{array}$ & 83.30 & 17.70 & 0.00 & 0.00 & 0.00 & 100.00 \\
\hline \multirow{2}{*}{10 ve üzeri } & Çalışan & 8 & 8 & 0 & 0 & 0 & 16 \\
\hline & $\begin{array}{l}\text { Oranı } \\
\text { (of) }\end{array}$ & 50.00 & 50.00 & 0.00 & 0.00 & 00 & 1.00 \\
\hline \multirow{2}{*}{$3-5$} & $\begin{array}{l}\text { Çalışan } \\
\text { Savas' }\end{array}$ & 6 & 0 & 1 & 1 & 0 & 8 \\
\hline & Oranı & 75.00 & 0.00 & 12.50 & 12.50 & 0.00 & 100.00 \\
\hline \multirow{2}{*}{$1-3$} & $\begin{array}{l}\text { Çalışan } \\
\text { Cavas }\end{array}$ & 2 & 0 & $\beta$ & 0 & 0 & 5 \\
\hline & $\begin{array}{l}\text { Orani } \\
\text { (ot) }\end{array}$ & 40.00 & 0.00 & 60.00 & 0.00 & 0.00 & 100.00 \\
\hline \multirow{2}{*}{$0-1$} & $\begin{array}{l}\text { Çalışan } \\
\text { Cavas }\end{array}$ & 1 & 0 & 1 & 1 & 0 & 3 \\
\hline & $\begin{array}{l}\text { Oranı } \\
\text { (ot) }\end{array}$ & 33.33 & 0.00 & 33.33 & 33.33 & 0.00 & 100.00 \\
\hline \multirow{2}{*}{$\begin{array}{l}\text { Yas Arallklarna Göre } \\
\text { Toplam Çalssan Saylart }\end{array}$} & $\begin{array}{l}\text { Çaltşan } \\
\text { Cawer }\end{array}$ & 32 & 11 & 5 & 2 & 0 & 50 \\
\hline & Oranı (\%) & 64.00 & 22.00 & 10.00 & 4.00 & 0.00 & 100.00 \\
\hline
\end{tabular}


Çalışmaya konu olan işyerleri ile bu iş yerlerinde çalışan kişilerin şimdiki iş yerlerinde çalışma sürelerine göre dağılım Çizelgesi 9'da verilmiştir. Buna göre, çalışanların yaş aralığı bakımından şuan çalışmakta oldukları işyerlerinde çalışma sürelerine göre dağılımı incelendiğinde en yüksek çalışan sayısının 25-40 yaş grubunda oldukları ve bu kişilerin 1-3 yıl çalıştıkları tespit edilmiştir.

Çizelge 9. Çalışmaya konu olan işyerleri ile bu işyerlerinde çalışan kişilerin şimdiki iş yerlerinde çalışma sürelerine göre dağılımı

\begin{tabular}{|c|c|c|c|c|c|c|c|}
\hline \multirow{2}{*}{\multicolumn{2}{|c|}{$\begin{array}{l}\text { Şuan ki İşyerinde Çalışma } \\
\text { Süresi (Yıl) }\end{array}$}} & \multicolumn{5}{|c|}{ Yaş Aralığı } & \multirow[t]{2}{*}{ 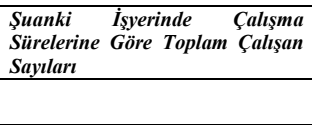 } \\
\hline & & $25-40$ & 40 ve üzeri & $18-25$ & $15-18$ & $14-15$ & \\
\hline \multirow{2}{*}{$1-3$} & $\begin{array}{l}\text { Çalışan } \\
\text { Sayısı }\end{array}$ & 10 & 0 & 3 & 0 & 0 & 13 \\
\hline & Oranı (\%) & 76.92 & 0.00 & 23.08 & 0.00 & 0.00 & 100.00 \\
\hline \multirow{2}{*}{$0-1$} & $\begin{array}{l}\text { Çalışan } \\
\text { Sayısı } \\
\end{array}$ & 7 & 1 & 2 & 2 & 0 & 12 \\
\hline & Oranı (\%) & 58.33 & 8.33 & 16.67 & 16.67 & 0.00 & 100.00 \\
\hline \multirow{2}{*}{ 5-10 } & $\begin{array}{l}\text { Çalışan } \\
\text { Sayısı }\end{array}$ & 4 & 7 & 0 & 0 & 0 & 11 \\
\hline & Oranı (\%) & 36.36 & 63.64 & 0.00 & 0.00 & 0.00 & 100.00 \\
\hline \multirow{2}{*}{$3-5$} & $\begin{array}{l}\text { Çalışan } \\
\text { Sayısı }\end{array}$ & 7 & 1 & 0 & 0 & 0 & 8 \\
\hline & Oranı (\%) & 87.50 & 12.50 & 0.00 & 0.00 & 0.00 & 100.00 \\
\hline \multirow{2}{*}{10 ve üzeri } & $\begin{array}{l}\text { Çalışan } \\
\text { Sayısı }\end{array}$ & 4 & 2 & 0 & 0 & 0 & 6 \\
\hline & Oranı (\%) & 66.67 & 33.33 & 0.00 & 0.00 & 0.00 & 100.00 \\
\hline \multirow{2}{*}{ 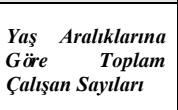 } & \begin{tabular}{|l|} 
Çalışan \\
Sayısı \\
\end{tabular} & 32 & 11 & 5 & 2 & 0 & 50 \\
\hline & Oranı (\%) & 64.00 & 22.00 & 10.00 & 4.00 & 0.00 & 100.00 \\
\hline
\end{tabular}

Çalışmaya konu olan işyerleri ile bu işyerlerinde çalışan kişilerin günlük çalışma sürelerine göre dağılım Çizelgesi 10'da verilmiştir. Buna göre, çalışanların yaş aralığı bakımından günlük çalışma sürelerine göre en yüksek çalışan sayısının 25-40 yaş grubunda oldukları ve bu kişilerin 6-9 saat çalıştıkları tespit edilmiştir.

Çizelge 10. Çalışmaya konu olan işyerleri ile bu işyerlerinde çalışan kişilerin günlük çalışma sürelerine göre dağglımı

\begin{tabular}{|c|c|c|c|c|c|c|c|}
\hline \multirow{2}{*}{$\begin{array}{l}\text { Günlük } \\
\text { (Saat) }\end{array}$} & \multirow[t]{2}{*}{ alışma } & \multicolumn{5}{|c|}{ Yaş Aralığı } & \multirow{3}{*}{\begin{tabular}{|l}
$\begin{array}{l}\text { Günlük Callsma Sürelerine } \\
\text { Göre Toplam } \\
\text { Sayllart }\end{array}$ \\
32 \\
\end{tabular}} \\
\hline & & \multirow{2}{*}{\begin{tabular}{|l|}
$25-40$ \\
21
\end{tabular}} & \multirow{2}{*}{\begin{tabular}{|l}
40 ve üzeri \\
5
\end{tabular}} & \multirow{2}{*}{\begin{tabular}{|l|}
$18-25$ \\
5
\end{tabular}} & \multirow{2}{*}{\begin{tabular}{|l}
$\mathbf{1 5 - 1 8}$ \\
1
\end{tabular}} & \multirow{2}{*}{\begin{tabular}{|l|}
$14-15$ \\
0
\end{tabular}} & \\
\hline & Çalışan Sayısı & & & & & & \\
\hline $0-3$ & Oranı (\%) & 65.63 & 15.63 & 15.63 & 3.11 & 0.00 & 100.00 \\
\hline \multirow{2}{*}{$9-12$} & Çalışan Sayısı & 10 & 6 & 0 & 0 & 0 & 16 \\
\hline & Oranı (\%) & 62.50 & 37.50 & 0.00 & 0.00 & 0.00 & 100.00 \\
\hline \multirow{2}{*}{$3-6$} & Çalışan Sayısı & 0 & 0 & 0 & 1 & 0 & 1 \\
\hline & Oranı (\%) & 0.00 & 0.00 & 0.00 & 100.00 & 0.00 & 100.00 \\
\hline \multirow{2}{*}{$0-3$} & Çalışan Sayısı & 1 & 0 & 0 & 0 & 0 & 1 \\
\hline & Oranı (\%) & 100.00 & 0.00 & 0.00 & 0.00 & 0.00 & 100.00 \\
\hline \multirow{2}{*}{12 ve Üzeri } & Çalışan Sayısı & 0 & 0 & 0 & 0 & 0 & 0 \\
\hline & Oranı (\%) & 0.00 & 0.00 & 0.00 & 0.00 & 0.00 & 0.00 \\
\hline \multirow{2}{*}{ 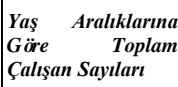 } & Çalışan Sayısı & 32 & 11 & 5 & 2 & 0 & 50 \\
\hline & Orant (\%) & 64.00 & 22.00 & 10.00 & 4.00 & 0.00 & 100.00 \\
\hline
\end{tabular}


Çalışmaya konu olan işyerlerinde çalışan kişilerin iş kazalarının önlenmesi/azaltılması için alınan önlemlerinin güvenlik yeterliliği algısına göre dağılımı Çizelgesi 11'de verilmiştir. Buna göre, katılımcıların çoğunluğu (\%52) kısmen katılıyorum şeklinde görüş bildirmiştir.

Çizelge 11. Çalışanların iş kazalarının önlenmesi/azaltılması için alınan önlemlerinin güvenlik yeterliliği algısına göre dağılımı

\begin{tabular}{|c|c|c|c|c|c|c|c|}
\hline \multirow{2}{*}{\multicolumn{2}{|c|}{$\begin{array}{l}\text { İs } \\
\text { Ö́nlenmesi/Azaltıalarının } \\
\text { Alınan Önlemler Yeterlidir }\end{array}$}} & \multicolumn{5}{|c|}{ Yaş Aralığı } & \multirow{2}{*}{ 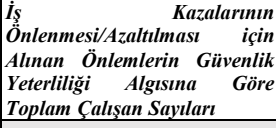 } \\
\hline & & $25-40$ & 40 ve üzeri & $18-25$ & $15-18$ & $14-15$ & \\
\hline \multirow{2}{*}{$\begin{array}{l}\text { Kismen } \\
\text { Katıllyorum }\end{array}$} & \begin{tabular}{|l|} 
Çalışan \\
Sayısı
\end{tabular} & 15 & 7 & 3 & 1 & 0 & 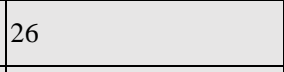 \\
\hline & Oranı (\%) & 57.70 & 26.92 & 11.54 & 3.84 & 0.00 & 100.00 \\
\hline \multirow{2}{*}{ Katılyyorum } & \begin{tabular}{|l|} 
Çalışan \\
Sayısı
\end{tabular} & 13 & 1 & 2 & 0 & 0 & 16 \\
\hline & Oranı (\%) & 81.25 & 6.25 & 12.50 & 0.00 & 0.00 & 100.00 \\
\hline \multirow{2}{*}{$\begin{array}{l}\text { Kesinlikle } \\
\text { Katıllyorum }\end{array}$} & \begin{tabular}{|l|} 
Çalışan \\
Sayısı \\
\end{tabular} & 3 & 2 & 0 & 0 & 0 & 5 \\
\hline & Oranı (\%) & 60.00 & 40.00 & 0.00 & 0.00 & 0.00 & 100.00 \\
\hline \multirow[t]{2}{*}{ Katılmıyorum } & \begin{tabular}{|l|}
$\begin{array}{l}\text { Çalşşan } \\
\text { Sayısı }\end{array}$ \\
\end{tabular} & 1 & 1 & 0 & 1 & 0 & 3 \\
\hline & Oranı (\%) & 33.33 & 33.33 & 0.00 & 33.33 & 0 & 100.00 \\
\hline \multirow{2}{*}{$\begin{array}{l}\text { Kesinlikle } \\
\text { Katılmıyorum }\end{array}$} & \begin{tabular}{|l|} 
Çalışan \\
Sayısı
\end{tabular} & 0 & 0 & 0 & 0 & 0 & 0 \\
\hline & Oranı (\%) & 0.00 & 0.00 & 0.00 & 0.00 & 0.00 & 100.00 \\
\hline \multirow{2}{*}{$\begin{array}{l}\text { Yas } \text { Arallklarina Göre } \\
\text { Toplam } \\
\text { Sayları }\end{array}$} & \begin{tabular}{|l|} 
Çalışan \\
Sayıst \\
\end{tabular} & 32 & 11 & 5 & 2 & 0 & 50 \\
\hline & Orant (\%) & 64.00 & 22.00 & 10.00 & 4.00 & 0.00 & 100.00 \\
\hline
\end{tabular}

Çalışmaya konu olan işyerlerinde çalışan kişilerin elektrik panosunun kilitli tutulmasının güvenlik yeterliliği algısına göre dağılım Çizelgesi 12.'de verilmiştir. Buna göre, çalışanların çoğunluğu (\%94'ü) olumlu yönde (katılıyorum ve kesinlikle katıllyorum) şeklinde görüş bildirmiştir.

Çizelge 12. Çalışanların elektrik panosunun kilitli tutulmasının güvenlik yeterliliği algısına göre dağılımı

\begin{tabular}{|c|c|c|c|c|c|c|c|}
\hline \multirow{2}{*}{\multicolumn{2}{|c|}{$\begin{array}{l}\text { Elektrik Panosunun Kilitli } \\
\text { Tutulması Olası Risklere } \\
\text { Karşı Beni Korumaktadır }\end{array}$}} & \multicolumn{5}{|c|}{ Yaş Aralı̆̆ } & \multirow{3}{*}{ 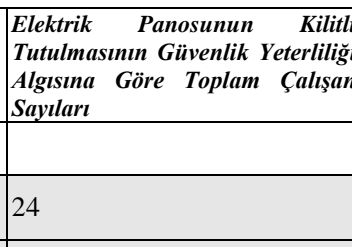 } \\
\hline & & \multirow{2}{*}{\begin{tabular}{|l|}
$\mathbf{2 5 - 4 0}$ \\
13 \\
\end{tabular}} & \multirow{2}{*}{\begin{tabular}{|l}
40 ve üzeri \\
6
\end{tabular}} & \multirow{2}{*}{\begin{tabular}{|l|}
$18-25$ \\
3 \\
\end{tabular}} & \multirow{2}{*}{\begin{tabular}{|l|}
$15-18$ \\
2
\end{tabular}} & \multirow{2}{*}{\begin{tabular}{|l} 
14-15 \\
0 \\
\end{tabular}} & \\
\hline Katılıvorum & \begin{tabular}{|l|} 
Çalısşan \\
Sayısı \\
\end{tabular} & & & & & & \\
\hline & Oranı (\%) & 54.17 & 25.00 & 12.50 & 8.33 & 0.00 & 100.00 \\
\hline \multirow{2}{*}{$\begin{array}{l}\text { Kesinlikle } \\
\text { Katıllyorum }\end{array}$} & \begin{tabular}{|l|} 
Çalışan \\
Sayısı
\end{tabular} & 16 & 5 & 2 & 0 & 0 & 23 \\
\hline & Oranı (\%) & 69.57 & 21.73 & 8.70 & 0.00 & 0.00 & 100.00 \\
\hline \multirow{2}{*}{$\begin{array}{l}\text { Kismen } \\
\text { Katıllyorum }\end{array}$} & \begin{tabular}{|l|}
$\begin{array}{l}\text { Çalışan } \\
\text { Sayısı }\end{array}$ \\
\end{tabular} & 3 & 0 & 0 & 0 & 0 & 3 \\
\hline & Oranı (\%) & 100.00 & 0.00 & 0.00 & 0.00 & 0.00 & 100.00 \\
\hline \multirow{2}{*}{ Katılmıyorum } & \begin{tabular}{|l|} 
Çalışan \\
Sayısı
\end{tabular} & 0 & 0 & 0 & 0 & 0 & 0 \\
\hline & Oranı (\%) & 0.00 & 0.00 & 0.00 & 0.00 & 0.00 & 0.00 \\
\hline \multirow{2}{*}{$\begin{array}{l}\text { Kesinlikle } \\
\text { Katılmıyorum }\end{array}$} & \begin{tabular}{|l|} 
Çalışan \\
Sayısı
\end{tabular} & 0 & 0 & 0 & 0 & 0 & 0 \\
\hline & Oranı (\%) & 0.00 & 0.00 & 0.00 & 0.00 & 0.00 & 0.00 \\
\hline \multirow{2}{*}{$\begin{array}{l}\text { Yaş } \\
\text { Göreraliklarina } \\
\text { Çalışan Sayılart }\end{array}$} & $\begin{array}{l}\text { Çalışan } \\
\text { Sayist } \\
\end{array}$ & 32 & 11 & 5 & 2 & 0 & 50 \\
\hline & Orant (\%) & 64.00 & 22.00 & 10.00 & 4.00 & 0.00 & 100.00 \\
\hline
\end{tabular}


Çalışmaya konu olan işyerlerinde çalışan kişilerin, elektrikli alet ve makinelere ait çalışma kılavuzlarının/talimatlarının güvenlik yeterliliği algısına göre dağılım Çizelgesi 13'de verilmiştir. Buna göre, çalışanların çoğunluğu (\%46) olumsuz yönde (katılmıyorum ve kesinlikle katılmıyorum), \%26'sı da kısmen katılıyorum şeklinde görüş bildirmiştir.

Çizelge 13. Çalışanların elektrikli alet ve makinelere ait çalışma kılavuzlarının/talimatlarının güvenlik yeterliliği algısına göre dağılımı

\begin{tabular}{|c|c|c|c|c|c|c|c|}
\hline \multicolumn{2}{|c|}{$\begin{array}{l}\text { Elektrikli Alet ve Makinelere ait } \\
\text { Çalışma Kılavuzları/Talimatları }\end{array}$} & \multicolumn{5}{|c|}{ Yaş Aralığı } & \multirow{2}{*}{$\begin{array}{l}\text { Elektrikli Alet ve Makinelere ait } \\
\text { Çalşsma } \\
\text { Kilavuzlarının/Talimatlarının } \\
\text { Güvenlik Yeterliliği Algısına Göre } \\
\text { Toplam Çalışan Sayllart }\end{array}$} \\
\hline $\begin{array}{l}\text { Güvenliğim } \\
\text { Düzeydedir }\end{array}$ & için Yeterli & $25-40$ & 40 ve üzeri & $18-25$ & $15-18$ & $14-15$ & \\
\hline \multirow{2}{*}{ Katılmıyorum } & Çalışan Sayısı & 13 & 6 & 0 & 1 & 0 & 20 \\
\hline & Oranı (\%) & 65.00 & 30.00 & 0.00 & 5.00 & 0.00 & 100.00 \\
\hline \multirow{2}{*}{$\begin{array}{l}\text { Kismen } \\
\text { Katılıyorum }\end{array}$} & Çalışan Sayısı & 9 & 2 & 2 & 0 & 0 & 13 \\
\hline & Oranı (\%) & 69.22 & 15.39 & 15.39 & 0.00 & 0.00 & 100.00 \\
\hline \multirow{2}{*}{ Katılıyorum } & Çalışan Sayısı & 4 & 2 & 2 & 1 & 0 & 9 \\
\hline & Oranı (\%) & 44.45 & 22.22 & 22.22 & 11.11 & 0.00 & 100.00 \\
\hline \multirow{2}{*}{$\begin{array}{l}\text { Kesinlikle } \\
\text { Katılıyorum }\end{array}$} & Çalışan Sayısı & 4 & 0 & 1 & 0 & 0 & 5 \\
\hline & Oranı (\%) & 80.00 & 0.00 & 20.00 & 0.00 & 0.00 & 100.00 \\
\hline \multirow{2}{*}{$\begin{array}{l}\text { Kesinlikle } \\
\text { Katılmıyorum }\end{array}$} & Çalışan Sayısı & 2 & 1 & 0 & 0 & 0 & 3 \\
\hline & Oranı (\%) & 66.67 & 33.33 & 0.00 & 0.00 & 0.00 & 100.00 \\
\hline \multirow{2}{*}{$\begin{array}{l}\text { Yas Araliklarıa } \text { Göre } \\
\text { Toplam } \\
\text { Saytart }\end{array}$} & Çalışan Sayısı & 32 & 11 & 5 & 2 & 0 & 50 \\
\hline & Oranı (\%) & 64.00 & 22.00 & 10.00 & 4.00 & 0.00 & 100.00 \\
\hline
\end{tabular}

Çalışmaya konu olan iş yerlerinde çalışan kişilerin bakım/onarım çalışmalarında ana panodan elektriğin kesilmesinin güvenlik yeterliliği algısına göre dağılım Çizelgesi 14'de verilmiştir. Buna göre, çalışanların çoğunluğu (\%90) olumlu yönde (katılıyorum ve kesinlikle katılıyorum) görüş bildirmişlerdir.

Çizelge 14. Çalışanların bakım/onarım çalışmalarında ana panodan elektriğin kesilmesinin güvenlik yeterliliği algısına göre dağılımı

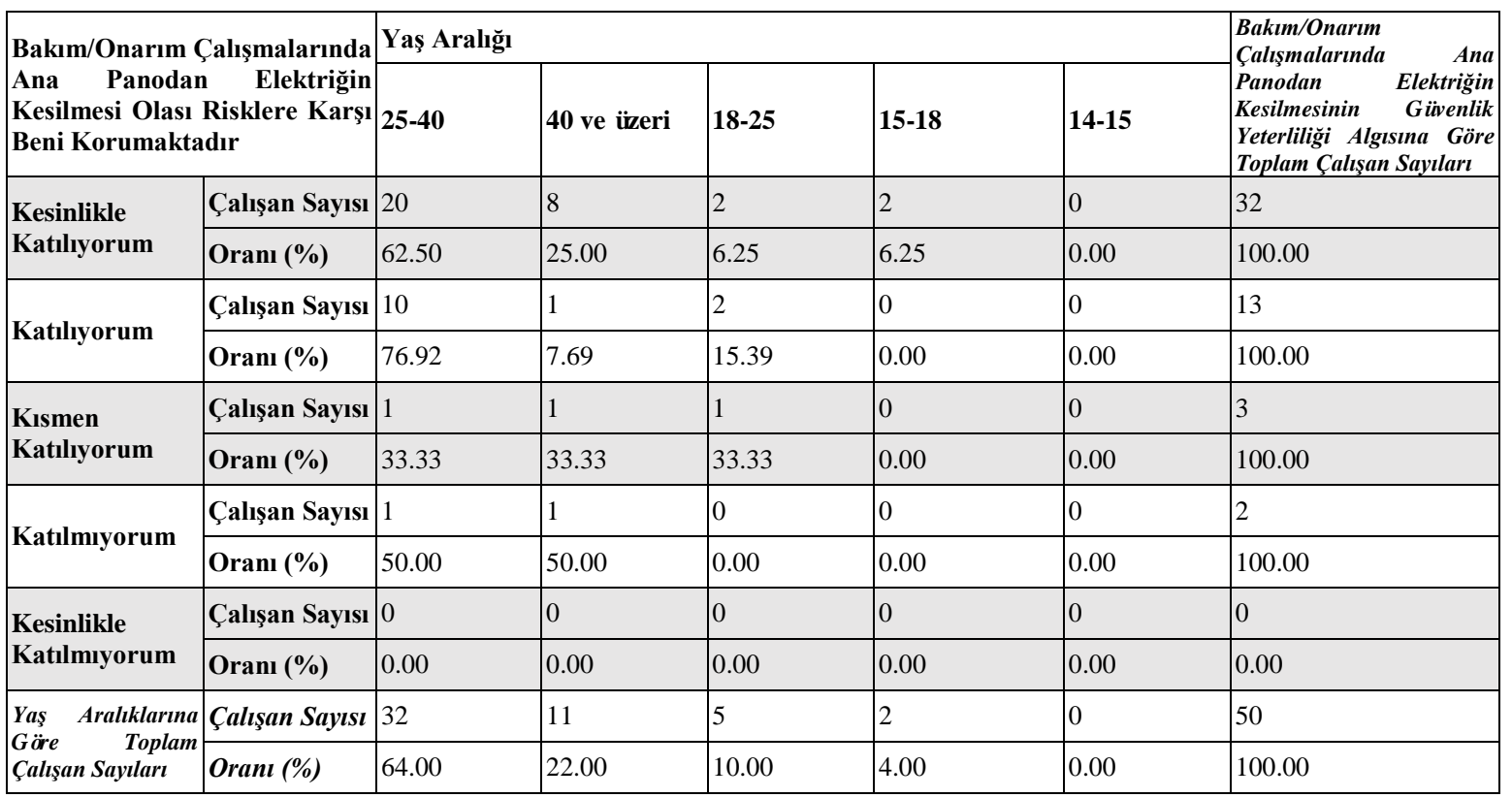


Çalışmaya konu olan iş yerlerinde çalışan kişilerin bakım/onarım çalışmalarında konulan uyarı işaret ve levhalarının güvenlik yeterliliği algısına göre dağılımı Çizelge 15.'te verilmiştir. Buna göre, katılımcıların \%42'si kısmen katılıyorum, \%22'si kesinlikle katılıyorum,\%20'si katılıyorum şeklinde olumlu görüş bildirmiştir.

Çizelge 15. Çalışanların bakım/onarım çalışmalarında konulan uyarı işaret ve levhalarının güvenlik yeterliliği algısına göre dağılımı

\begin{tabular}{|c|c|c|c|c|c|c|c|}
\hline \multirow{2}{*}{\multicolumn{2}{|c|}{$\begin{array}{l}\text { Bakım/Onarım Çalışmalarında } \\
\text { Konulan Uyarı İsaret ve } \\
\text { Levhaları Güvenliğim için } \\
\text { Yeterli Düzeydedir }\end{array}$}} & \multicolumn{5}{|c|}{ Yaş Aralığı } & \multirow{2}{*}{ 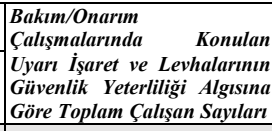 } \\
\hline & & $25-40$ & 40 ve üzeri & $18-25$ & $15-18$ & $14-15$ & \\
\hline \multirow{2}{*}{$\begin{array}{l}\text { Kismen } \\
\text { Katıllyorum }\end{array}$} & \begin{tabular}{|l} 
Çalışan \\
Sayısı
\end{tabular} & 13 & 5 & 3 & 0 & 0 & 21 \\
\hline & Oranı (\%) & $61.9 \%$ & $23.8 \%$ & $14.3 \%$ & $0.0 \%$ & 0.00 & $100.0 \%$ \\
\hline \multirow{2}{*}{$\begin{array}{l}\text { Kesinlikle } \\
\text { Katılıyorum }\end{array}$} & \begin{tabular}{|l|}
$\begin{array}{l}\text { Çalışan } \\
\text { Sayısı }\end{array}$ \\
\end{tabular} & 7 & 2 & 1 & 1 & 0 & 11 \\
\hline & Oranı (\%) & $63.6 \%$ & $18.2 \%$ & $9.1 \%$ & $9.1 \%$ & 0.00 & $100.0 \%$ \\
\hline \multirow{2}{*}{ Katılyyorum } & \begin{tabular}{|l} 
Çalışan \\
Sayısı \\
\end{tabular} & 7 & 2 & 1 & 0 & 0 & 10 \\
\hline & Oranı (\%) & $70.0 \%$ & $20.0 \%$ & $10.0 \%$ & $0.0 \%$ & 0.00 & $100.0 \%$ \\
\hline \multirow{2}{*}{ Katılmıyorum } & \begin{tabular}{|l|}
$\begin{array}{l}\text { Çalşşan } \\
\text { Sayısı }\end{array}$ \\
\end{tabular} & 5 & 2 & 0 & 1 & 0 & 8 \\
\hline & Oranı (\%) & $62.5 \%$ & $25.0 \%$ & $0.0 \%$ & $12.5 \%$ & 0.00 & $100.0 \%$ \\
\hline \multirow{2}{*}{$\begin{array}{l}\text { Kesinlikle } \\
\text { Katılmıyorum }\end{array}$} & \begin{tabular}{|l|} 
Çalışan \\
Sayısı
\end{tabular} & 0 & 0 & 0 & 0 & 0 & 0 \\
\hline & Oranı (\%) & 0.00 & 0.00 & 0.00 & 0.00 & 0.00 & 0.00 \\
\hline \multirow{2}{*}{$\begin{array}{ll}\text { Yass } & \text { Araliklarına } \\
\text { Göre } & \text { Toplam } \\
\text { Çalış̧an Sayılart }\end{array}$} & \begin{tabular}{|l|l|} 
Çalışan \\
Sayıst
\end{tabular} & 32 & 11 & 5 & 2 & 0 & 50 \\
\hline & Oranı (\%) & $64.0 \%$ & $22.0 \%$ & $10.0 \%$ & $4.0 \%$ & 0.00 & $100.0 \%$ \\
\hline
\end{tabular}

Çalışmaya konu olan işyerlerinde çalışan kişilerin bakım/onarım çalışmalarına ait çalışma kılavuzlarının/talimatlarının güvenlik yeterliliği algısına göre dağılımı Çizelge 16' da verilmiştir. Buna göre, katılımcıların \% 52'si olumsuz yönde (katılmıyorum ve kesinlikle katılmıyorum), \%28'i de kısmen katılıyorum görüş bildirmiştir.

Çizelge 16. Çalışanların bakım/onarım çalışmalarına ait çalışma kılavuzlarının /talimatlarının güvenlik yeterliliği algısına göre dağılımı

\begin{tabular}{|c|c|c|c|c|c|c|c|}
\hline \multirow{2}{*}{\multicolumn{2}{|c|}{$\begin{array}{l}\text { Bakım/Onarım Çalışmalarına ait } \\
\text { Çalış̧a Kılavuzları/Talimatları } \\
\text { Güvenliğim için Yeterli Düzeydedir }\end{array}$}} & \multicolumn{5}{|c|}{ Yaş Aralığı } & \multirow{2}{*}{$\begin{array}{l}\text { Bakım/Onarım Çalışmalarına ait } \\
\text { Çalşsma } \\
\text { Kilavuzlarının/Talimatlarının } \\
\text { Güvenlik Yeterliliği Algisına } \\
\text { Göre Toplam Çalışan Saylart }\end{array}$} \\
\hline & & $25-40$ & 40 ve üzeri & $18-25$ & $15-18$ & $14-15$ & \\
\hline \multirow{2}{*}{ Katılmıyorum } & \begin{tabular}{|l} 
Çalışan \\
Sayısı \\
\end{tabular} & 13 & 7 & 3 & 1 & 0 & 24 \\
\hline & Oranı (\%) & 54.16 & 29.17 & 12.50 & 4.17 & 0.00 & 100.00 \\
\hline \multirow{2}{*}{$\begin{array}{l}\text { Kismen } \\
\text { Katılıyorum }\end{array}$} & \begin{tabular}{|l|} 
Çalışan \\
Sayısı \\
\end{tabular} & 9 & 4 & 1 & 0 & 0 & 14 \\
\hline & Oranı (\%) & 64.29 & 28.57 & 7.14 & 0.00 & 0.00 & 100.00 \\
\hline \multirow{2}{*}{ Katılıyorum } & \begin{tabular}{|l|} 
Çalışan \\
Sayısı \\
\end{tabular} & 4 & 0 & 0 & 1 & 0 & 5 \\
\hline & Oranı (\%) & 80.00 & 0.00 & 0.00 & 20.00 & 0.00 & 100.00 \\
\hline \multirow{2}{*}{$\begin{array}{l}\text { Kesinlikle } \\
\text { Katılıyorum }\end{array}$} & \begin{tabular}{|l|} 
Çalışan \\
Sayısı \\
\end{tabular} & 4 & 0 & 1 & 0 & 0 & 5 \\
\hline & Oranı (\%) & 80.00 & 0.00 & 20.00 & 0.00 & 0.00 & 100.00 \\
\hline \multirow{2}{*}{$\begin{array}{l}\text { Kesinlikle } \\
\text { Katılmıyorum }\end{array}$} & \begin{tabular}{|l|} 
Çalışan \\
Sayısı \\
\end{tabular} & 2 & 0 & 0 & 0 & 0 & 2 \\
\hline & Oranı (\%) & 100.00 & 0.00 & 0.00 & 0.00 & 0.00 & 100.00 \\
\hline \multirow{2}{*}{$\begin{array}{l}\text { Yaş Aralıklarına Göre } \\
\text { Toplam } \quad \text { Çalışan } \\
\text { Sayılart }\end{array}$} & $\begin{array}{l}\text { Çalışan } \\
\text { Sayısı } \\
\end{array}$ & 32 & 11 & 5 & 2 & 0 & 50 \\
\hline & Oranı (\%) & 64.00 & 22.00 & 10.00 & 4.00 & 0.00 & 100.00 \\
\hline
\end{tabular}


Çalışmaya konu olan işyerlerinde çalışan kişilerin makine ve ekipmanların ayar/bakım/onarım çalışmalarında güvenlik yeterliliği algısına göre dağılımı Çizelge 17'de verilmiştir. Buna göre, katılımcıların \% 96'sı olumlu yönde görüş bildirmiştir.

Çizelge 17. Çalışanların makine ve ekipmanların ayar/bakım/onarım çalışmalarında güvenlik yeterliliği algısına göre dağılımı

\begin{tabular}{|c|c|c|c|c|c|c|c|}
\hline \multicolumn{2}{|c|}{$\begin{array}{l}\text { Makine ve Ekipmanların } \\
\text { Ayar/Bakım/Onarım }\end{array}$} & \multicolumn{5}{|c|}{ Yaş Aralığı } & \multirow{2}{*}{ 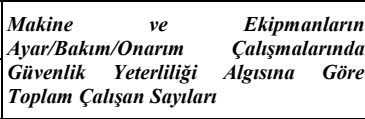 } \\
\hline $\begin{array}{l}\text { Çalışmaları } \\
\text { Güvenlik }\end{array}$ & $\begin{array}{r}\text { Yapılırken } \\
\text { Endişesi }\end{array}$ & $25-40$ & 40 ve üzeri & $18-25$ & $15-18$ & $14-15$ & \\
\hline \multirow{2}{*}{$\begin{array}{l}\text { Kesinlikle } \\
\text { Katılıyorum }\end{array}$} & \begin{tabular}{|l|} 
Çalışan \\
Savısı
\end{tabular} & 29 & 9 & 1 & 1 & 0 & 40 \\
\hline & $\begin{array}{l}\text { Oranı } \\
(\%)\end{array}$ & 72.50 & 22.50 & 2.50 & 2.50 & 0.00 & 100.00 \\
\hline \multirow{2}{*}{ Katılıyorum } & $\begin{array}{l}\text { Çalıșan } \\
\text { Savısı }\end{array}$ & 2 & 2 & 3 & 1 & 0 & 8 \\
\hline & $\begin{array}{l}\text { Oranı } \\
(\%)\end{array}$ & 25.00 & 25.00 & 37.50 & 12.50 & 0.00 & 100.00 \\
\hline \multirow{2}{*}{$\begin{array}{l}\text { Kısmen } \\
\text { Katılıyorum }\end{array}$} & $\begin{array}{l}\text { Çalışan } \\
\text { Savısı }\end{array}$ & 1 & 0 & 1 & 0 & 0 & 2 \\
\hline & $\begin{array}{l}\text { Oranı } \\
(\%)\end{array}$ & 50.00 & 0.00 & 50.00 & 0.00 & 0.00 & 100.00 \\
\hline \multirow{2}{*}{ Katılmıyorum } & $\begin{array}{l}\text { Çalışan } \\
\text { Savısı }\end{array}$ & 0 & 0 & 0 & 0 & 0 & 0 \\
\hline & $\begin{array}{l}\text { Oranı } \\
(\%)\end{array}$ & 0.00 & 0.00 & 0.00 & 0.00 & 0.00 & 0.00 \\
\hline \multirow{2}{*}{$\begin{array}{l}\text { Kesinlikle } \\
\text { Katılmıyorum }\end{array}$} & $\begin{array}{l}\text { Çalışan } \\
\text { Savisı }\end{array}$ & 0 & 0 & 0 & 0 & 0 & 0 \\
\hline & \begin{tabular}{|l|} 
Oranı \\
$(\%)$
\end{tabular} & 0.00 & 0.00 & 0.00 & 0.00 & 0.00 & 0.00 \\
\hline \multirow{2}{*}{$\begin{array}{lr}\text { Yaș } & \text { Aralıklarına } \\
\text { Göre } \quad \text { Toplam } \\
\text { Çalışan Sayıları }\end{array}$} & \begin{tabular}{|l|} 
Çalışan \\
Savisı
\end{tabular} & 32 & 11 & 5 & 2 & 0 & 50 \\
\hline & \begin{tabular}{|l} 
Orant \\
$(\%)$
\end{tabular} & 64.00 & 22.00 & 10.00 & 4.00 & 0.00 & 100.00 \\
\hline
\end{tabular}

Çalışmaya konu olan işyerlerinde çalışan kişilerin makine ve ekipmanların ayar/bakım/onarım çalışmalarına ait çalışma kılavuzlarının/talimatlarının güvenlik yeterliliği algısına göre dağılım Çizelge 18 'de verilmiştir. Buna göre, katılımcıların \%44'ü kısmen katılıyorum, \%32'si katılıyorum, \%12'si ise katılmıyorum şeklinde görüş bildirmiştir. Kısmen katılıyorum diyen grup 25-40 yaş aralığındadır.

Çizelge 18. Çalışanların makine ve ekipmanların ayar/bakım/onarım çalışmalarına ait çalışma kılavuzlarının/talimatlarının güvenlik yeterliliği algısına göre dağılımı

\begin{tabular}{|c|c|c|c|c|c|c|c|}
\hline \multirow{2}{*}{\multicolumn{2}{|c|}{\begin{tabular}{|lrl} 
& \\
Makine & ve & Ekipmanların \\
Ayar/Bakım/Onarım Çalışmalarına ait \\
Çalışma & Kılavuzları/Talimatları \\
Güvenliğim için Yeterli Düzeydedir
\end{tabular}}} & \multicolumn{5}{|c|}{ Yaş Aralığ } & \multirow{2}{*}{ 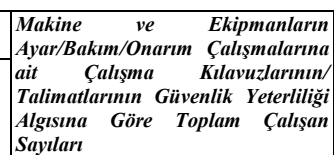 } \\
\hline & & $25-40$ & 40 ve üzeri & $18-25$ & $15-18$ & $14-15$ & \\
\hline \multirow{2}{*}{$\begin{array}{l}\text { Kismen } \\
\text { Katılıyorum }\end{array}$} & \begin{tabular}{|l|} 
Çalışan \\
Sayısı \\
\end{tabular} & 17 & 4 & 0 & 1 & 0 & ( \\
\hline & \begin{tabular}{|l|} 
Oranı (\%) \\
\end{tabular} & 77.27 & 18.18 & 0.00 & 4.55 & 0.00 & 100.00 \\
\hline \multirow[t]{2}{*}{ Katılıyorum } & $\begin{array}{l}\text { Çalışan } \\
\text { Sayısı }\end{array}$ & 9 & 5 & 2 & 0 & 0 & 16 \\
\hline & Oranı (\%) & 56.25 & 31.25 & 12.50 & 0.00 & 0.00 & 100.00 \\
\hline \multirow{2}{*}{ Katılmıyorum } & $\begin{array}{l}\text { Çalışan } \\
\text { Sayısı } \\
\end{array}$ & 2 & 1 & 2 & 1 & 0 & 6 \\
\hline & Oranı (\%) & 33.33 & 16.67 & 33.33 & 16.67 & 0.00 & 100.00 \\
\hline \multirow{2}{*}{\begin{tabular}{|l|} 
Kesinlikle \\
Katılmıyorum
\end{tabular}} & $\begin{array}{l}\text { Çalışan } \\
\text { Sayısı }\end{array}$ & 3 & 1 & 1 & 0 & 0 & 5 \\
\hline & Oranı (\%) & 60.00 & 20.00 & 20.00 & 0.00 & 0.00 & 100.00 \\
\hline \multirow{2}{*}{$\begin{array}{l}\text { Kesinlikle } \\
\text { Katılıyorum }\end{array}$} & $\begin{array}{l}\text { Çalışan } \\
\text { Sayısı } \\
\end{array}$ & 1 & 0 & 0 & 0 & 0 & 1 \\
\hline & Oranı (\%) & 100.00 & 0.00 & 0.00 & 0.00 & 0.00 & 100.00 \\
\hline \multirow{2}{*}{$\begin{array}{|lr|}\text { Yaş } & \text { Aralıklarına } \\
\text { Göre } & \text { Toplam } \\
\text { Çalışan } & \text { Sayılart }\end{array}$} & Çalışan Sayısı & 32 & 11 & 5 & 2 & 0 & 50 \\
\hline & Oranı (\%) & 64.00 & 22.00 & 10.00 & 4.00 & 0.00 & 100.00 \\
\hline
\end{tabular}


Çalışmaya konu olan iş yerlerinde çalışan kişilerin makine koruyucularının takılı ve sağlam durumda bulunmasının güvenlik yeterliliği algısına göre dağılım Çizelge 19'da verilmiştir. Buna göre, katılımcıların \% 70’i olumlu yönde(katılıyorum ve kesinlikle katılıyorum), \%28'i de kısmen katılıyorum şeklinde görüş bildirmiştir.

Çizelge 19. Çalışanların makine koruyucularının takılı ve sağlam durumda bulunmasının güvenlik yeterliliği algısına göre dağılımı

\begin{tabular}{|c|c|c|c|c|c|c|c|}
\hline \multirow{2}{*}{\multicolumn{2}{|c|}{$\begin{array}{l}\text { Makine Koruyucularının } \\
\text { Takılı ve Sağlam Durumda } \\
\text { Bulunması Olası Risklere } \\
\text { Karşı Beni Korumaktadır }\end{array}$}} & \multicolumn{5}{|c|}{ Yaş Aralığı } & \multirow{2}{*}{ 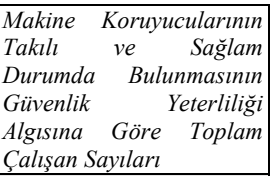 } \\
\hline & & $25-40$ & 40 ve üzeri & $18-25$ & $15-18$ & $14-15$ & \\
\hline \multirow[t]{2}{*}{ Katıllyorum } & \begin{tabular}{|l|} 
Çalışan \\
Sayısı
\end{tabular} & 9 & 4 & 3 & 2 & 0 & (2) \\
\hline & Oranı (\%) & 50.00 & 22.22 & 16.67 & 11.11 & 0.00 & 100.00 \\
\hline \multirow{2}{*}{$\begin{array}{l}\text { Kesinlikle } \\
\text { Katılıyorum }\end{array}$} & \begin{tabular}{|l|} 
Çalışan \\
Sayısı
\end{tabular} & 12 & 3 & 2 & 0 & 0 & 17 \\
\hline & Oranı (\%) & 70.59 & 17.65 & 11.76 & 0.00 & 0.00 & 100.00 \\
\hline \multirow{2}{*}{$\begin{array}{l}\text { Kismen } \\
\text { Katılıyorum }\end{array}$} & $\begin{array}{l}\text { Çalışan } \\
\text { Sayısı }\end{array}$ & 11 & 3 & 0 & 0 & 0 & 14 \\
\hline & Oranı (\%) & 78.57 & 21.43 & 0.00 & 0.00 & 0.00 & 100.00 \\
\hline \multirow{2}{*}{ Katılmıyorum } & \begin{tabular}{|l|}
$\begin{array}{l}\text { Çalışan } \\
\text { Sayısı }\end{array}$ \\
\end{tabular} & 0 & 1 & 0 & 0 & 0 & 1 \\
\hline & Oranı (\%) & 0.00 & 100.00 & 0.00 & 0.00 & 0.00 & 100.00 \\
\hline \multirow{2}{*}{$\begin{array}{l}\text { Kesinlikle } \\
\text { Katılmıyorum }\end{array}$} & $\begin{array}{l}\text { Çalışan } \\
\text { Sayısı }\end{array}$ & 0 & 0 & 0 & 0 & 0 & 0 \\
\hline & Oranı (\%) & 0.00 & 0.00 & 0.00 & 0.00 & 0.00 & 0.00 \\
\hline \multirow{2}{*}{$\begin{array}{l}\text { Yaş Aralıklarına } \\
\text { Göre Toplam } \\
\text { Çalışan Saytlart }\end{array}$} & \begin{tabular}{|l} 
Çalışan \\
Saytst \\
\end{tabular} & 32 & 11 & 5 & 2 & 0 & 50 \\
\hline & Oranı (\%) & 64.00 & 22.00 & 10.00 & 4.00 & 0.00 & 100.00 \\
\hline
\end{tabular}

Çalışmaya konu olan iş yerlerinde duman detektörü bulunmasının güvenlik yeterliliği algısına göre dağılım Çizelge 20'de verilmiştir. Buna göre, katılımcıların \%62'si olumlu (katılıyorum ve kesinlikle katılıyorum), \%14'ü de kısmen katılıyorum şeklinde görüş bildirmiştir.

Çizelge 20. İşyerlerinde duman detektörü bulunmasının güvenlik yeterliliği algısına göre dağılımı

\begin{tabular}{|c|c|c|c|c|c|c|c|}
\hline \multirow{2}{*}{\multicolumn{2}{|c|}{ 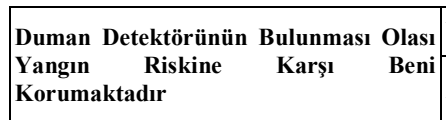 }} & \multicolumn{5}{|c|}{ Yaş Aralığı } & \multirow{3}{*}{ 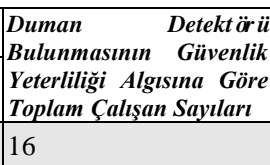 } \\
\hline & & \multirow{2}{*}{\begin{tabular}{|l|}
$25-40$ \\
11 \\
\end{tabular}} & \multirow{2}{*}{$\begin{array}{l}40 \text { ve üzeri } \\
2\end{array}$} & \multirow{2}{*}{$\begin{array}{l}18-25 \\
2 \\
\end{array}$} & \multirow{2}{*}{$\begin{array}{l}\mathbf{1 5 - 1 8} \\
1\end{array}$} & \multirow{2}{*}{$\begin{array}{l}\text { 14-15 } \\
0 \\
\end{array}$} & \\
\hline Kesinlikle & Çalışan Sayısı & & & & & & \\
\hline Katılıyorum & Oranı (\%) & 68.75 & 12.50 & 12.50 & 6.25 & 0.00 & 100.00 \\
\hline \multirow{2}{*}{ Katılıyorum } & Çalışan Sayısı & 8 & 4 & 2 & 1 & 0 & 15 \\
\hline & Oranı (\%) & 53.33 & 26.67 & 13.33 & 6.67 & 0.00 & 100.00 \\
\hline \multirow{2}{*}{$\begin{array}{l}\text { Kismen } \\
\text { Katılıyorum }\end{array}$} & Çalışan Sayısı & 3 & 3 & 1 & 0 & 0 & 7 \\
\hline & Oranı (\%) & 42.85 & 42.85 & 14.30 & 0.00 & 0.00 & 100.00 \\
\hline \multirow{2}{*}{$\begin{array}{l}\text { Kesinlikle } \\
\text { Katılmıyorum }\end{array}$} & Çalışan Sayısı & 5 & 1 & 0 & 0 & 0 & 6 \\
\hline & Oranı (\%) & 83.33 & 16.67 & 0.00 & 0.00 & 0.00 & 100.00 \\
\hline \multirow{2}{*}{ Katılmıyorum } & Çalışan Sayısı & 5 & 1 & 0 & 0 & 0 & 6 \\
\hline & Oranı (\%) & 83.33 & 16.67 & 0.00 & 0.00 & 0.00 & 100.00 \\
\hline \multirow{2}{*}{$\begin{array}{lr}\text { Yaş } & \text { Aralıklarına } \\
\text { Göre } & \text { Toplam } \\
\text { Çalışan } & \text { Sayıları } \\
\end{array}$} & Çalışan Sayısı & 32 & 11 & 5 & 2 & 0 & 50 \\
\hline & Oranı (\%) & 64.00 & 22.00 & 10.00 & 4.00 & 0.00 & 100.00 \\
\hline
\end{tabular}


Çalışmaya konu olan iş yerlerindeyangın tatbikatlarının sıklığının güvenlik yeterliliği algısına göre dağılım Çizelgesi 21'de verilmiştir. Buna göre, katılımcıların \% 70'i olumsuz yönde (katılmıyorum ve kesinlikle katılmıyorum),\% 26's1 da kısmen katılıyorum şeklinde görüş bildirmiştir.

Çizelge 21. İşyerlerinde yangın tatbikatlarının sıklığının güvenlik yeterliliği algısına göre dağılımı

\begin{tabular}{|c|c|c|c|c|c|c|c|}
\hline \multirow{2}{*}{\multicolumn{2}{|c|}{$\begin{array}{l}\text { Yangın } \quad \text { Tatbikatlarının } \\
\text { Sıklığı Olası Yangın Riskine } \\
\text { Karşı Beni Korumaktadır }\end{array}$}} & \multicolumn{5}{|c|}{ Yaş Aralığı } & \multirow{2}{*}{$\begin{array}{|lr|}\text { Yangın } & \text { Tatbikatlarının } \\
\text { Sıklığının } & \text { Güvenlik } \\
\text { Yeterliliği Algısına Göre } & \text { Alsı } \\
\text { Toplam Çalışan Sayıları } \\
\end{array}$} \\
\hline & & $25-40$ & 40 ve üzeri & $18-25$ & $15-18$ & $14-15$ & \\
\hline \multirow{2}{*}{ Katılmıyorum } & \begin{tabular}{|l} 
Çalışan \\
Sayısı
\end{tabular} & 13 & 9 & 2 & 0 & 0 & $\begin{array}{llll} & \\
\end{array}$ \\
\hline & Oranı (\%) & 54.17 & 37.50 & 8.33 & 0.00 & 0.00 & 100.00 \\
\hline \multirow{2}{*}{$\begin{array}{l}\text { Kismen } \\
\text { Katılıyorum }\end{array}$} & \begin{tabular}{|l|}
$\begin{array}{l}\text { Çalışan } \\
\text { Sayısı }\end{array}$ \\
\end{tabular} & 10 & 1 & 2 & 0 & 0 & 13 \\
\hline & Oranı (\%) & 76.92 & 7.69 & 15.39 & 0.00 & 0.00 & 100.00 \\
\hline \multirow{2}{*}{\begin{tabular}{l|} 
Kesinlikle \\
Katılmıyorum
\end{tabular}} & $\begin{array}{l}\text { Çalışan } \\
\text { Sayısı } \\
\end{array}$ & 8 & 1 & 1 & 1 & 0 & 11 \\
\hline & Oranı (\%) & 72.70 & 9.10 & 9.10 & 9.10 & 0.00 & 100.00 \\
\hline \multirow{2}{*}{ Katılıyorum } & \begin{tabular}{|l|} 
Çalışan \\
Sayısı
\end{tabular} & 0 & 0 & 0 & 1 & 0 & 1 \\
\hline & Oranı (\%) & 0.00 & 0.00 & 0.00 & 100.00 & 0.00 & 100.00 \\
\hline \multirow{2}{*}{$\begin{array}{l}\text { Kesinlikle } \\
\text { Katılıyorum }\end{array}$} & \begin{tabular}{|l|} 
Çalışan \\
Sayısı \\
\end{tabular} & 1 & 0 & 0 & 0 & 0 & 1 \\
\hline & Oranı (\%) & 100.00 & 0.00 & 0.00 & 0.00 & 0.00 & 100.00 \\
\hline \multirow{2}{*}{$\begin{array}{l}\text { Yaş } \\
\text { Aralıklarına } \\
\text { Göre Toplam } \\
\text { Çalışan } \\
\text { Sayılart } \\
\end{array}$} & $\begin{array}{l}\text { Çalışan } \\
\text { Saytsi } \\
\end{array}$ & 32 & 11 & 5 & 2 & 0 & 50 \\
\hline & Oranı (\%) & 64.00 & 22.00 & 10.00 & 4.00 & 0.00 & 100.00 \\
\hline
\end{tabular}

Çalıșmaya konu olan işyerlerindekiilkyardımcıların bilgi ve donanımının güvenlik yeterliliği algısına göre dağılım Çizelgesi 22.'de verilmiştir. Buna göre, katılımcıların \%30’u kısmen katılıyorum, \%30'u katılmıyorum, \%16'sı kesinlikle katılıyorum, \%14'ü kesinlikle katılmıyorum, \%10’u da katılıyorum şeklinde görüş bildirmiştir.

Çizelge 22. İşyerlerindekiilkyardımcıların bilgi ve donanımının güvenlik yeterliliği algısına göre dağılımı

\begin{tabular}{|c|c|c|c|c|c|c|c|}
\hline \multirow{2}{*}{\multicolumn{2}{|c|}{$\begin{array}{l}\text { İlkyardımcıların Bilgi ve } \\
\text { Donanımı Güvenliğim için } \\
\text { Yeterlidir } \\
\end{array}$}} & \multicolumn{5}{|c|}{ Yaş Aralı̆̆ } & \multirow{3}{*}{\begin{tabular}{|l}
$\begin{array}{l}\text { Ilkyardımcıların Bilgi ve } \\
\text { Donanımının Güvenlik } \\
\text { Yeterliliği Algısına Göre } \\
\text { Toplam Çalışan Sayılart }\end{array}$ \\
15
\end{tabular}} \\
\hline & & \multirow{2}{*}{\begin{tabular}{|l|}
$25-40$ \\
9
\end{tabular}} & \multirow{2}{*}{\begin{tabular}{|l}
40 ve üzeri \\
4
\end{tabular}} & \multirow{2}{*}{ 18-25 } & \multirow{2}{*}{\begin{tabular}{|l|}
$15-18$ \\
0
\end{tabular}} & \multirow{2}{*}{$\begin{array}{l}14-15 \\
0\end{array}$} & \\
\hline Kismen & \begin{tabular}{|l|l|} 
Çalışan \\
Sayısı
\end{tabular} & & & & & & \\
\hline & Oranı (\%) & 60.00 & 26.67 & 13.33 & 0.00 & 0.00 & 100.00 \\
\hline \multirow{2}{*}{ Katılmıyorum } & \begin{tabular}{|l|} 
Çalışan \\
Sayısı \\
\end{tabular} & 6 & 5 & 3 & 1 & 0 & 15 \\
\hline & Oranı (\%) & 40.00 & 33.33 & 20.00 & 6.67 & 0.00 & 100.00 \\
\hline \multirow{2}{*}{$\begin{array}{l}\text { Kesinlikle } \\
\text { Katılıyorum }\end{array}$} & \begin{tabular}{|l} 
Çalışan \\
Sayısı \\
\end{tabular} & 7 & 1 & 0 & 0 & 0 & 8 \\
\hline & Oranı (\%) & 87.50 & 12.50 & 0.00 & 0.00 & 0.00 & 100.00 \\
\hline \multirow{2}{*}{$\begin{array}{l}\text { Kesinlikle } \\
\text { Katılmıyorum }\end{array}$} & \begin{tabular}{|l|} 
Çalışan \\
Sayısı \\
\end{tabular} & 6 & 1 & 0 & 0 & 0 & 7 \\
\hline & Oranı (\%) & 85.71 & 14.29 & 0.00 & 0.00 & 0.00 & 100.00 \\
\hline \multirow[t]{2}{*}{ Katılıyorum } & \begin{tabular}{|l|} 
Çalışan \\
Sayısı \\
\end{tabular} & 4 & 0 & 0 & 1 & 0 & 5 \\
\hline & Oranı (\%) & 80.00 & 0.00 & 0.00 & 20.00 & 0.00 & 100.00 \\
\hline \multirow{2}{*}{$\begin{array}{l}\text { Yaş Aralıklarına } \\
\text { Görer Toplam } \\
\text { Çalışan Saytlart }\end{array}$} & \begin{tabular}{|l|} 
Çalışan \\
Sayıst \\
\end{tabular} & 32 & 11 & 5 & 2 & 0 & 50 \\
\hline & Oranı (\%) & 64.00 & 22.00 & 10.00 & 4.00 & 0.00 & 100.00 \\
\hline
\end{tabular}




\section{Sonuçlar ve Öneriler}

Bilecik ilindeki küçük ölçekli mobilya üretimi yapan işyerlerinde çalışan kişilerin maruz kaldığı iş kazaları ile bu kazalara bakış açılarının ve çalışmakta oldukları işyerlerinde iş sağlığı ve güvenliği açısından yapılan faaliyetlerin yeterlilik düzeylerinin belirlenmesine yönelik elde edilen sonuçlara göre;

- Çalışanlar yaşlarına göre kategorize edildiğinde ağırlıklı olarak 25-40 yaş aralığında olduğu, sigara kullanım durumuna göre kategorize edildiğinde ise büyük çoğunluğunun sigara kullandığı,

- İşyerlerinde görevli ilkyardım personelinin bilgi ve donanım açısından eksikliklerinin olduğu,

- Acil durum ve yangın tatbikatlarının yetersiz olduğu,

- Uyarı işaret ve levhaları ile çalışma kılavuzları ve talimatlarının güvenlik gereksinimlerini tam olarak karşılayamadığ 1 belirlenmiştir.

\section{Bu bilgiler ıșığında șu önerilerde bulunulabilir:}

- İşyerlerinde görev yapan ilk yardımcılara, periyodik olarak eğitimler verilerek ilkyardım malzemelerini kaza anında etkin biçimde kullanmaları sağlanmalıdır.

- İşyerinde olası risklere karşı tüm çalışanlar uyarılmalı, eğitilmeli ve bilinçlendirilmelidir. İş güvenliği uzmanı tarafından işletme içinde sürekli denetimler yapılmalı ve bunlar periyodik raporlar halinde üst yönetime sunulmalıdır.

- Sigara kullanımı kişinin kendi sağlı̆̆ını tehdit etmekle kalmayıp, çevresindeki kişiler için de toplumsal bir sorun haline gelmiştir. Bu durum, özellikle işyerlerinde iş kazalarını ve meslek hastalıklarını artırdığı gibi kişiyi zamanla çeşitli sigara kullanımından kaynaklı sağlık sorunlarına maruz bıraktığı için çalışma verimini de düşürmektedir. $\mathrm{Bu}$ nedenle, sigara kullanımını önleme/azaltma konusunda gerekli çalışmalar yapılarak, çalışanların sigarayı bırakması teşvik edilmelidir.

- Yapılan tüm işlere ait uyarı işaret ve levhaları ile güvenli çalışma kılavuzları ve çalışma talimatlarının olası tüm riskleri göz önünde bulundurularak yeniden hazırlanmalidır.

- Acil durum ve yangın konusundaki eğitimlerin ve bunlara ilişkin tatbikatların sayısı ve niteliği artırılmalıdır.

\section{Teşekkür}

Bu çalışma, Gazi Üniversitesi Teknoloji Fakültesi Ağaçişleri Endüstri Mühendisliği Bölümü Mezunu Mustafa UĞUZ tarafından hazırlanan Lisans Bitirme Tezinden üretilmiştir.

\section{Kaynaklar}

Arseven, F., (2004), Yeni İş Kanununun İş Sağlığı ve Güvenliği Yaklaşımı. İşveren Dergisi, 47: 23-27.

Birtekin, Ö., (2015), Hatay ve Gaziantep illeri kapsamında bulunan ahşap işleri ve mobilya üretim sektöründeki işletmelerde iş sağlığ 1 ve güvenliği tedbirlerinin ve bilinebilirliğinin araştırılması, yüksek lisans tezi, Zirve Üniversitesi Sosyal Bilimler Enstitüsü, Gaziantep.

ÇSGB, (2012), İş sağlı̆̆1 ve güvenliğine ilişkin işyeri tehlike sınıfları tebliği, Resmi Gazete, 26.12.2012, Say1: 28509. 
Ford, M.T., Tetrick, L.E., (2011), Relation among occupational hazards, Attitudes And Safety Performance. Journal Of Cccupational Health Psychology, 16(1), 48-66.

Gedik, T., İlhan, A., (2014), Sakarya ili mobilya imalatçılarında iş sağlığı ve iş güvenliği üzerine bir inceleme, SDÜ Orman Fakültesi Dergisi, 15, 123-129.

Kalkan, T., B., (2013), İş sağlığı ve güvenliği risk değerlendirme çalışmaları için bir metodoloji oluşturma ve bir mobilya işletmesinde uygulanması, yüksek lisans tezi, Kırıkkale Üniversitesi Fen Bilimleri Enstitüsü, Kırıkkale.

Koç, S., (2016), Mobilya sektöründe ergonomik risk değerlendirmesi: bir mobilya fabrikasında saha çalışması, yüksek lisans tezi, Hacettepe Üniversitesi Fen Bilimleri Enstitüsü, Ankara.

Şen, H., Çınar, H., (2017), Mobilya ürün yaşam döngüsünde iş sağlığı ve güvenliği analizi, Mühendislik Bilimleri ve Tasarım Dergisi, 5, 235-246.

Şimşek, C., (2012), Meslek hastalıkları ve işle ilgili hastalıklar tanı rehberi. İSGİP, 350, Ankara.

Turan, G., (2013), Mobilya üretimi sürecinde karşılaşılan başlıca önemli çevresel etkilerin çalışan sağlığı açısından değerlendirilmesi, yüksek lisans tezi, Namık Kemal Üniversitesi Fen Bilimleri Enstitüsü, Tekirdağ.

Ulay, G., Engür, M., O., (2016), Bir mobilya işletmesinde iş güvenliği uygulamaları ve bunların işletmeye maliyeti, Selçuk Üniversitesi Selçuk-Teknik Dergisi, Özel Say1-2 (UMK-2015), 1260-1274.

Uygun, Z., (2015), Mobilya sektöründe iş sağlı̆̆ı ve güvenliğinde riskler ve önlemleri A ve B işletmelerinin İSG uygulamaları yönünden karşılaştırılması, yüksek lisans tezi, Gediz Üniversitesi Fen Bilimleri Enstitüsü, İzmir.

Yılmaz, K., (2015), Ağaç işleri endüstrisinde iş sağlığı ve güvenliği ile ilgili mevcut durumun belirlenmesi: mobilya sektörü örneği, yüksek lisans tezi, Hacettepe Üniversitesi Fen Bilimleri Enstitüsü, Ankara.

Zor, M., Yazıcı, H., Karakavuz, H., (2017), Mobilya imalatçılarında iş güvenliği algısı üzerine bir inceleme: Zonguldak ili örneği, İleri Teknoloji Bilimleri Dergisi, 6(3), 11431151. 